\title{
Anthropogenic effects on interaction outcomes: examples from insect-microbial symbioses in forest and savanna ecosystems
}

\author{
Diana L. Six ${ }^{1}$, Michael Poulsen ${ }^{2,3}$, Allison K. Hansen ${ }^{4}$, Michael J. Wingfield ${ }^{5}$, Jolanda Roux ${ }^{6}$, \\ Paul Eggleton ${ }^{7}$, Bernard Slippers ${ }^{8}$ and Timothy D. Paine ${ }^{9}$
}

(1) Department of Ecosystem and Conservation Sciences, College of Forestry and Conservation, The University of Montana, Missoula, MT 59812, USA.

(2) Department of Bacteriology, University of Wisconsin, Madison, WI 53706, USA.

(3) Section for Ecology and Evolution, University of Copenhagen, Copenhagen 2100, Denmark.

(4) Department of Ecology and Evolutionary Biology, West Campus, Yale University, PO Box 27388, West Haven, CT 06516-7388, USA.

(5) Forestry and Agricultural Biotechnology Institute, University of Pretoria, Pretoria, 0002, Republic of South Africa.

(6) Department of Microbiology and Plant Pathology, Forestry and Agricultural Biotechnology Institute, University of Pretoria, Pretoria 0002, Republic of South Africa.

(7) Natural History Museum, London SW7 5BD, United Kingdom.

(8) Department of Genetics, Forestry and Agricultural Biotechnology Institute, University of Pretoria, Pretoria 0002, Republic of South Africa.

(9) Department of Entomology, University of California, Riverside, CA 92521, USA.

\section{Diana L. Six}

Email: diana.six@cfc.umt.edu

\begin{abstract}
The influence of humans on ecosystem dynamics has been, and continues to be, profound. Anthropogenic effects are expected to amplify as human populations continue to increase. Concern over these effects has given rise to a large number of studies focusing on impacts of human activities on individual species or on biotic community structure and composition. Lacking are studies on interactions, particularly mutualisms. Because of the role of mutualisms in ecosystem stability, such studies are critically needed if we are to begin to better understand and predict the responses of ecosystems to anthropogenic change. Most organisms are involved in at least one mutualism, and many in several. Mutualisms facilitate the ability of partners to exploit particular habitats and resources, and play a large role in determining ecological boundaries. When change disrupts, enhances, or introduces new organisms into a mutualism, the outcome and stability of the original partnership(s) is altered as are effects of the symbiosis on the community and ecosystem as a whole. In this paper, using examples from six microbe-insect mutualisms in forest and savanna settings, we showcase how varied and complex the responses of mutualisms can be to an equally varied set of anthropogenic influences. We also show how alterations of mutualisms may ramify throughout affected systems. We stress that researchers must be cognizant that many observed changes in the behaviors, abundances, and distributions of organisms due to human activities are likely to be mediated by mutualists which may alter predictions and actual outcomes in significant ways.
\end{abstract}




\section{Introduction}

Humans are the most powerful biological force affecting ecosystems on Earth. In forest and savanna ecosystems, anthropogenic effects have been, and remain, considerable. Such effects are expected to increase as human populations grow and pressures on these systems concomitantly increase. As the impacts and extent of human activities intensify, it is imperative that we understand how they will influence the intricate mutualisms that so strongly influence ecosystem functions and processes.

Forest and savanna ecosystems are home to much of the biodiversity on our planet. They also provide many of the critical ecosystem services humans require for survival (Costanza 1997). However, these ecosystems are also among those most impacted by human activities. Deforestation continues at a rapid rate in many parts of the world as humans convert vast areas to agricultural and urban uses (Wade et al. 2003; Kowero et al. 2006). Forests and savannas that remain are often fragmented, reducing effective population sizes, increasing extinctions, and reducing or halting migration (Saunders et al. 1991; Cushman 2006; Aguilar et al. 2006). In many forests, human practices such as logging, removal of preferred species, selective growth of desired species, and fire suppression have led to compositional and demographic changes (e.g., conversion of old growth to younger, less diverse forests), which in turn have led to an array of emergent problems including increases in pests, changes in fire regimes, and reduced biodiversity and ecosystem resilience (Fuller et al. 1998; McCullough et al. 1998; Keane et al. 2002). Agricultural expansion into forests and savannas has likewise impacted the function and resiliency of these ecosystems. The human introduction (both accidental and intentional) of exotic organisms is directly modifying these ecosystems with cascading effects on native biota (Lindenmayer and Noss 2006). In addition, anthropogenic warming is directly and indirectly altering many forest and savanna ecosystems through effects on the frequency, intensity, seasonality, and extent of disturbance, and on plant survival, pathogen susceptibility, soil community composition and function, and insect population responses (Dale et al. 2001; Logan et al. 2003; Kurz et al. 2008). Changes in disturbance regimes and temperature and precipitation patterns due to global warming are driving ecosystem shifts that can be accompanied by drastic changes in species abundance and distributions, and numerous extinctions (IPCC 2007). Interactions of anthropogenic factors can challenge ecosystems further. For example, climate change is predicted to result in substantially altered geographic ranges for many organisms (Parmesan and Yohe 2003). However, many organisms will not be able to track areas suitable for their survival if their habitat is severely fragmented (Erasmus et al. 2002; Thomas et al. 2006).

Considerable attention has been directed towards understanding and mediating effects of anthropogenic change on forest ecosystems. This attention has primarily focused on individual organisms, particularly the very abundant (e.g., pests) or the very rare (e.g., threatened and endangered), or on community-level analyses assessing impacts on biodiversity. Studies have rarely considered impacts on interactions involving multiple trophic levels (Davis et al. 1998; Janson et al. 2009; Six 2009). In particular, very little attention has been given to effects of anthropogenic change on mutualisms, despite the fact that these symbioses are among the most important drivers of ecosystem function, structure, and process (Boucher et al. 1982; Margulis and Fester 1991; Douglas 1994; Maynard Smith and Szathmary 1995; Del-Claro and Torezan-Silingardi 2009; Kiers et al. 2010), and alterations in their composition and outcomes are likely to ramify throughout affected systems (Six 2009; Kiers et al. 2010).

In this paper, we consider the manner in which anthropogenic changes to forest and savanna ecosystems can directly and indirectly influence symbioses and result in feedbacks that ultimately influence the ecosystem as a whole (Fig. 1). We confine our treatment to mutualisms occurring between insects and microbes. Both groups are highly sensitive to their environment and respond 
rapidly to change, and together, make up a vast portion of the biodiversity of these ecosystems. Very importantly, mutualisms involving these groups include key ecosystem engineers as well as pests. Indeed, it is participation in mutualisms that have allowed these organisms to become so highly successful and influential in the ecosystems within which they occur.

In the next sections, we discuss six insect-microbial symbioses that affect forests and savannas in significant ways. Each is affected by anthropogenic change, although the type of human activity influencing each symbiosis and the response by the symbioses vary considerably. In each case, effects on these symbioses, and subsequently on the ecosystems within which they occur, are already, or likely will become, profound.

\section{Anthropogenic Effects on Forests}
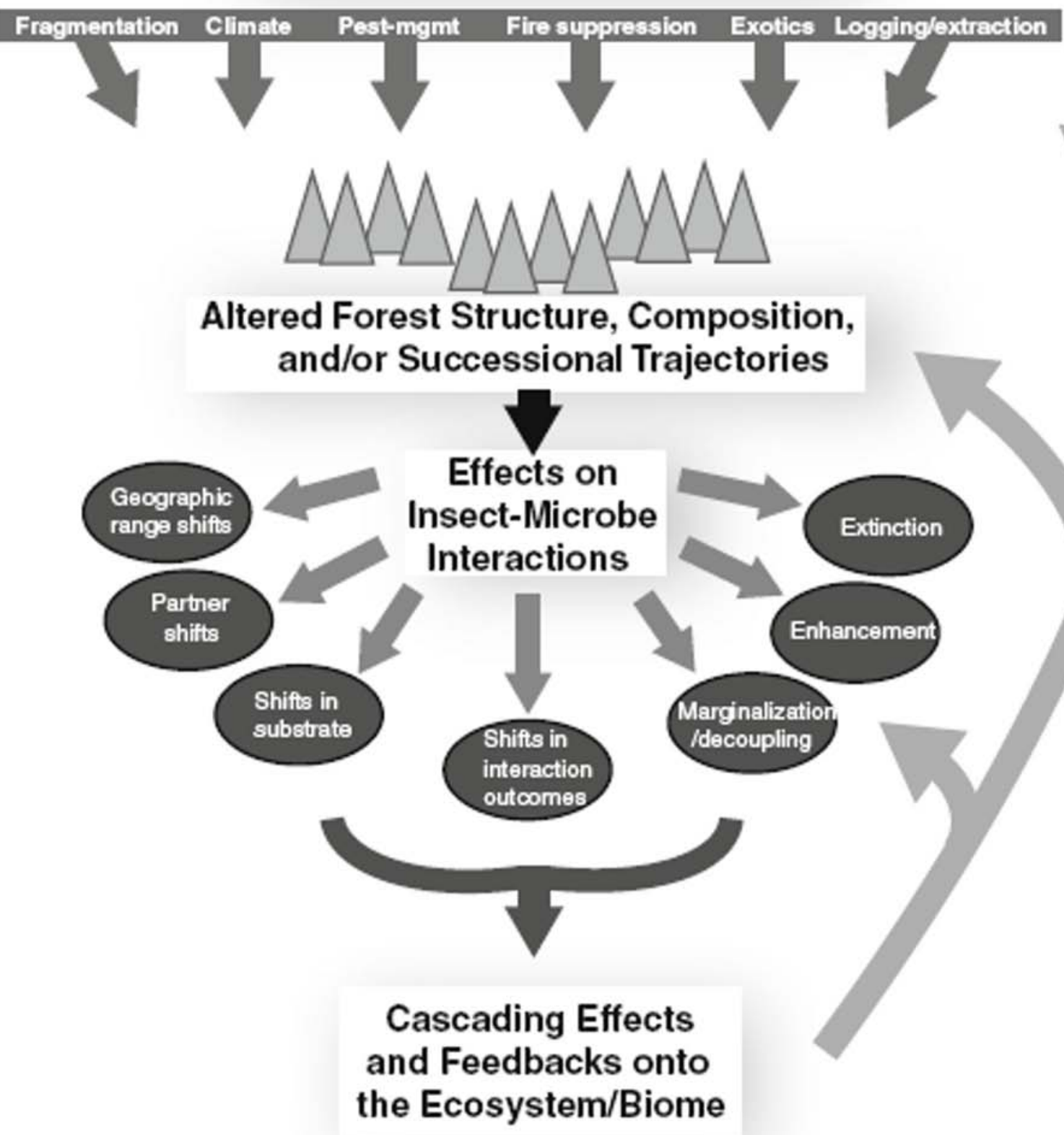

Figure 1. Anthropogenic effects on forests. 


\title{
Forest/savanna insect-microbe mutualisms affected by anthropogenic forces
}

\author{
Bark beetle-fungus symbioses
}

Bark beetles (Coleoptera: Curculionidae, Scolytinae) colonizing conifers commonly form symbioses with fungi. However, the type of interaction can vary from facultative to obligate, and from mutualistic to commensal to antagonistic (Six 2003; Six and Wingfield 2011). Bark beetles construct galleries under the outer bark in the phloem layer where they lay eggs and the larvae feed. As parent beetles construct galleries they inoculate the tree with symbiotic fungi that then grow in both phloem and sapwood. In the context of beetle nutrition, phloem is a nutrient poor substrate. Bark beetles have evolved two strategies for contending with this problem. Some construct long feeding galleries and consume large amounts of phloem relative to their final adult size (Ayres et al. 2000). These species do not appear to gain benefit from feeding on fungi and the fungi they carry are not highly specific. Other bark beetles use fungal associates to compensate for the nutritional limitations of their diet, particularly low levels of nitrogen and a lack of usable sterols (Ayres et al. 2000; Bentz and Six 2006; Bleiker and Six 2008). These beetles construct short feeding galleries and spend much of their development feeding on phloem colonized by fungi or in chambers where they feed mainly on fungi (Six and Paine 1998; Ayres et al. 2000). These associations appear to be obligate mutualisms; without fungal feeding, beetle fecundity and size is reduced (Six and Paine 1998; Bleiker and Six 2007) and reproduction may not occur (Six and Paine 1998). Fungi involved in these associations are typically highly consistent with, and specific to, their beetle hosts (Six 2003). Indicative of their reliance on fungi, many of these beetles have evolved complex, highly selective integumental structures called mycangia, in which they carry fungi to new trees enhancing the potential for vertical transmission and ensuring continuity of the association from generation to generation (Six 2003).

The fungi associated with bark beetles are primarily Ascomycotina in the Ophiostomatales (Ophiostoma, Ceratocystiopsis, Grosmannia), although a few beetle species carry Microascales (Ceratocystis) or Basidiomycotina (Entomocorticium). Most bark beetle-fungus symbioses involve multiple fungal partners (Six and Klepzig 2004). The various fungi associated with a host can play redundant or differing roles. For example, the southern pine beetle, Dendroctonus frontalis, possesses two nutritional symbionts, Entomocorticium sp. A and Ceratocystiopsis ranaculosus, which are consistently carried in the beetle mycangium. It also carries an antagonist, Ophiostoma minus, loosely on its exoskeleton. Ophiostoma minus is a mutualist of Tarsonemus mites which are phoretic on the beetles (Lombardero et al. 2003; Hofstetter et al. 2006a, b). The relative prevalence of each of these fungi has a substantial impact on host population dynamics. Individuals that develop with Entomocorticium are larger and have higher lipid contents than those that develop with C. ranaculosus (Coppedge et al. 1995), and beetle populations with a higher prevalence of Entomocorticium exhibit more rapid population growth (Bridges 1983; Goldhammer et al. 1990; Coppedge et al. 1995). In contrast, as the prevalence of the antagonist, O. minus, increases, beetle populations decrease. Indeed, the collapse of outbreaks of $D$. frontalis can be attributed to this fungus reaching a particular threshold of prevalence within trees (Lombardero et al. 2003; Hofstetter et al. 2006a, b). The prevalence of $O$. minus is directly related to temperature. When temperatures support increases in mite vectors, this increases the prevalence of $O$. minus within the tree relative to the beneficial fungi causing a decline in beetle survival (Lombardero et al. 2003; Hofstetter et al. 2006a, b). 


\section{Importance to ecosystems}

The life history of a bark beetle affects how it impacts the ecosystem within which it occurs. Primary beetles are aggressive tree killers capable of developing extensive outbreaks during which most mature host trees in the affected area can be killed (Carroll et al. 2004). These insects act simultaneously as pests and as critical natural disturbance agents that maintain the function and structure of the forest ecosystems within which they have coevolved (Raffa et al. 2008). For example, the mountain pine beetle develops extensive outbreaks in lodgepole pine and is the primary agent, along with fire, that determines the successional dynamics in lodgepole pine forests (Stone and Wolfe 1996).

In contrast to primary bark beetles, secondary bark beetles are limited to colonizing weakened or dying trees, or trees recently killed by other factors such as fire or wind (Wood 1982). These insects are seldom considered pests and typically act to thin dense tree stands, open gaps enhancing biodiversity, initiate decomposition, and provide food for birds and other wildlife. Extensive outbreaks of these beetles are rare and occur only when large areas of trees become highly stressed, such as often occurs during periods of extended drought or after windthrow, which can provide ample breeding material supporting short-term population increases.

\section{Anthropogenic effects}

In many forests, human practices such as logging, removal of preferred species, selective growth of desired species, and fire suppression have led to compositional and demographic changes of host trees. These factors have had considerable impacts on bark beetle distribution and abundance, and consequently, their impacts on forests. For example, fire suppression and some logging practices have led to more expansive areas of susceptible forest than occurred in the past (Taylor and Carroll 2004; Raffa et al. 2008). In these forests, the replacement of a mosaic of stands of varying susceptibilities with expanses of homogenous forest now support more extensive bark beetle outbreaks.

In some areas, forest management practices have radically changed the spatial structure and species composition of conifer forests. For example, in the southern US commercial forestry has increased the extent of pine species susceptible to the southern pine beetle while reducing the extent of resistant pines (Perkins and Matlack 2002). Planting practices have also simultaneously increased the connectivity of susceptible pines across the landscape, facilitating more severe and extensive outbreaks of the beetle (Perkins and Matlack 2002). The widespread practice of replanting native forests after harvest or disturbance such as fire, with trees of the same species, but of different geographic origins and genetic makeup, has also likely greatly altered the susceptibility of many forests to bark beetle infestation (Ledig 1992).

Silvicultural practices alter forest structure and composition in ways that affect the beetle-fungus symbiosis as a unit. However, other types of human-caused changes may act to fundamentally alter the symbiosis itself. In the case of climate change, increasing temperatures will affect hosts and symbionts differently, altering the composition, dynamics, and outcomes of the interaction (Six 2009). A spectacular example of how strongly even small changes in temperature can affect an insect-microbe symbiosis, is found in the mountain pine beetle-fungus symbiosis. Responses by the insect partner to temperature are the most obvious and best understood. In recent years, increasing temperatures have resulted in greater survival and productivity, and more rapid development of the beetle (Carroll et al. 2004; Régneirè and Bentz 2007; Bentz and Schen-Lagenheim 2007). Warming has allowed rapid expansions of beetle (and fungal) populations as well as remarkable geographic range expansions to the north and east into regions where the beetle did not previously exist (Carroll et al. 2004; Lee et al. 2007). In the eastern expansion, the beetle is now attacking Pinus banksiana 
(Jack pine), a species previously not encountered by this insect. Driven by increased temperatures and facilitated by previous land management practices, the current outbreak of mountain pine beetle is now the largest on record for any bark beetle species.

Warming trends are also responsible for recent outbreaks of mountain pine beetle in sub-alpine whitebark pine (Pinus albicaulis) forests (Logan et al. 2002; Bentz and Schen-Lagenheim 2007; Logan and MacFarlane 2010). Historically, the mountain pine beetle was mostly excluded from the sub-alpine by cold temperatures accompanied by a short growing season. Under these conditions, the beetle underwent a two-year life cycle (Amman 1973). Such an extended life cycle is maladaptive for the mountain pine beetle which would need to survive two winters as well as complete development in a tree dead for 2 years. Under these conditions, mountain pine beetles were excluded, or their populations remained extremely low, in sub-alpine systems. Recently, however, increased temperatures have allowed the beetle to switch to a one-year life cycle in high elevations, which has allowed the development of large populations and rapidly spreading outbreaks. Whitebark pine, a keystone species, is not expected to recover in many areas (Hicke et al. 2006; Logan and MacFarlane 2010) with significant cascading effects within the subalpine as well as adjacent ecosystems.

The population dynamics of the mountain pine beetle are strongly influenced by stand conditions and environmental triggers including temperature and drought (Carroll et al. 2004). However, dynamics are also likely affected by the beetle's fungal complement. The two mutualistic fungi of the beetle, G. clavigera and O. montium, like the beetles, are extremely sensitive to temperature, which strongly affects their ability to capture resources (food, space, and hosts), reproduce, and compete with other fungi (Carlile et al. 2001). Temperature also strongly affects the relative prevalence of the two fungi with the host beetle (Six and Bentz 2007; Rice et al. 2008). Six and Bentz (2007) observed that temperature determines which of the two fungal symbionts is vectored by dispersing adults over a season. G. clavigera sporulates in pupal chambers and is acquired in mycangia of newly emerged adults shortly before dispersal when temperatures are relatively cool, while $O$. montium is likewise acquired when temperatures are relatively warm. Temperature may also affect the relative abundance of the fungi over the developmental period of the beetle as strong shifts in the prevalence of the two have been observed from the egg to the adult stage (Adams and Six 2006). These effects are likely to have substantial impacts on beetle fitness by affecting which fungus is predominantly fed upon and dispersed by the beetle. Studies have found that beetles that feed on G. clavigera are larger and more fecund than those that feed on O. montium. This indicates that when temperatures are cool, this fungus is likely to dominate within the tree, and beetles consequently, are likely to have higher fitness and a higher potential for expanding populations. Likewise, if temperatures are relatively cool during dispersal, G. clavigera will be vectored to a greater degree to new host trees.

The stability of bark beetle-fungus symbioses is likely to be affected by warming trends (Hofstetter et al. 2006a, b; Six and Bentz 2007). As temperatures rise, this will increasingly select for fungal partners tolerant of warm conditions and against those that require cool conditions. This has a number of ramifications for both symbionts and hosts. In the short term, host fitness is likely to be enhanced or reduced depending upon which symbionts are favored. If a superior symbiont is favored, this should support robust beetle populations with a greater potential for population increase. Conversely, if an inferior symbiont is favored, then the host beetle may become marginalized. Over the long term, increasing temperatures could lead to the loss (and potential extinction) of some symbionts, and consequently, a reduction in the diversity of the symbiont community associated with a beetle (Six and Bentz 2007). Temperature-driven shifts in fungi may also affect population dynamics of the beetles indirectly through effects on natural enemies. Volatiles released by symbiotic fungi are used by some parasitoids to locate their bark beetle hosts (Boone et al. 2008; Adams and Six 2008). Therefore, shifts in the relative abundances of fungal 
associates, or their loss, may influence the degree to which these wasps are able to locate hosts and regulate host populations.

It has been suggested that the individualistic responses of symbionts to environmental conditions, including temperature, may play an important role in maintaining host beetle ecological flexibility. When environmental conditions are unpredictable or variable relative to host generation time, host specialization on one symbiont may not be favored (Baker 2003; Six and Bentz 2007). Under such circumstances, possessing multiple symbionts may aid the host by increasing the probability that at least one symbiont is present (and functional) under prevailing environmental conditions (Six and Bentz 2007). The loss of a symbiont(s) due to altered climatic conditions may, therefore, decrease the ecological flexibility of a host. Ultimately, this may act to restrict its ecological and geographical range to only the conditions under which its remaining symbiont(s) can exist. Finally, new temperature regimes may exclude all symbionts, completely decoupling the symbiosis.

Under climate scenarios predicted for western North America, warming will have serious impacts on the mountain pine beetle-fungus symbiosis. Warming should act to decrease the prevalence of $G$. clavigera, the superior symbiont, and increase the prevalence of $O$. montium, the inferior symbiont. As warming proceeds, G. clavigera may be lost from many populations. Indeed, in recent years, mountain pine beetles at sites experiencing hot summers have been observed to carry extremely low levels of G. clavigera (Six and Bentz 2007; Bleiker and Six 2008). In addition, aposymbiotic beetles have been collected in areas experiencing very high summer temperatures (Bleiker and Six 2008 ) indicating that dispersal of $O$. montium will also be reduced as very hot summers become the norm. Aposymbiotic beetles are small and likely have low fitness (Bleiker and Six 2008) indicating that range contractions of the beetle may occur in areas where conditions shift to the point that neither symbiont is supported.

While the thought that mountain pine beetle may be seriously negatively impacted by climate change in the long term may initially give managers a reason to rejoice, it is important to remember that these insects are critical natural agents of disturbance. A change in their role in forest ecosystems could be as undesirable as the effects we are now seeing as a consequence of anthropogenic-induced changes in the occurrence and severity of another important natural disturbance, fire, in western US forests and elsewhere (Keane et al. 2002).

Another considerable effect of humans on bark beetle-fungus symbioses is their introduction into novel environments around the globe. Many introduced beetles are likely to exploit the same habitats as native beetles, leading to cohabitation within the same substrate. When this occurs, exotic beetles may encounter fungi associated with native beetles and potentially add these as associates. Conversely, native beetles may acquire exotic fungi from co-occurring exotic beetles. When exotic and native beetles are capable of 'fungus-swapping' and have overlapping but different host tree ranges, this can increase the number of tree species exposed to fungi carried by both exotic and native bark beetles. Even when native beetles do not acquire the fungi associated with cooccurring exotics, the fungi associated with exotics may competitively exclude the normal fungal partners of native beetles with potentially serious effects for native biodiversity. While few studies have been conducted investigating these possibilities, there is ample evidence that fungal 'swaps' and new acquisitions are occurring (Jacobs et al. 2004; Lu et al. 2009a, b), as well as evidence in at least one case where an exotic beetle (and potentially its fungal complement) is being competitively displaced by another exotic beetle where the two beetles co-occur (Lee et al. 2009).

Given that some bark beetle associates are pathogens, their movement around the world is cause for concern (Wingfield et al. 2010). While these fungi do not pose significant threats in their home ranges, they may act differently in new environments and in hosts that have not evolved proper defenses (Brasier 2001). One example where fungal associates may be contributing to a more 
aggressive behavior of an introduced beetle is that of the red turpentine beetle (D. valens). This beetle was introduced into China from North America around 1980. Around 1999, populations of the beetle rapidly expanded and spread across several provinces (Yan et al. 2005). By 2003, over ten million Chinese red pine (P. tabuliformis), as well as many other pines had been killed. Isolation studies revealed at least ten species of ophiostomatoid fungi including several from North America, as well as at least one strain from Europe (Q. Lu et al. 2008; Lu et al. 2009a). The rest were apparently acquired by the beetle in China. Tests revealed that several were pathogens (Lu et al. 2009b). At this point, evidence indicates that the fungi alone are not responsible for the aggressiveness of this beetle in China. Rather, it is likely due to a combination of the fungi, a lack of coevolved resistance in the host tree, and drought stress (Lu et al. 2009a).

\section{Ambrosia beetle-fungus symbioses}

Ambrosia beetles (Coleoptera: Curculionidae, Scolytinae) are close relatives to bark beetles but differ in how they colonize trees and their reliance on fungi as food. Unlike bark beetles, which reside in the phloem and feed on both fungi and tree tissues, ambrosia beetles build gallery systems deep within the sapwood and actively cultivate fungi in 'gardens' as their sole food source (Norris 1979).

Associations between ambrosia beetles and their fungal symbionts are complex and typically involve a community of fungi (Norris 1979; Beaver 1989; Six 2003). The fungi have often been categorized as primary and secondary (or auxiliary) symbionts (Batra 1967). The primary fungi are typically highly consistent with their beetle hosts and are transported in the mycangia of adult beetles (Six 2003). These fungi often predominate in the fungal gardens and provide nutrition for both adults and larvae. Primary fungi occur mainly in the Ascomycotina genera, Ambrosiella and Raffaelea, which are closely related to ophiostomatoid bark beetle fungi, but with altered morphologies and a complete loss of sexuality (Norris 1979; Blackwell and Jones 1997; PaulinMahady et al. 2002; Massoumi-Alamouti et al. 2009). Secondary fungi are often less consistently associated and, for most, their roles remain unknown (Beaver 1989; Kok et al. 1970). One nonophiostomatoid Ascomycete genus, Fusarium, is very commonly isolated from ambrosia beetles. Some Fusarium species are primary symbionts while others appear to be secondaries (Norris 1979; Morales-Ramos et al. 2000).

\section{Importance to ecosystems}

The vast majority of ambrosia beetles colonize trees or woody plants that have been recently killed, or are dying or severely stressed. Through their tunneling actions, they contribute substantially to the degradation of wood and nutrient cycling (Kühnholn et al. 2003). Very few species kill healthy trees and ambrosia beetles have not been typically considered pests except when they infest cut logs prior to milling (Beaver and Loyttyniemi 1985; Kühnholn et al. 2003).

\section{Anthropogenic effects}

One of the major concerns with both climate change and the increasing number of introductions of exotics around the world is the potential for an increase in emerging pests. Ambrosia beetles, which have seldom been thought of as threats to forests in the past, are now at the forefront of concern in this area. In recent years, there have been increasing numbers of reports of ambrosia beetles attacking apparently healthy trees, and together with their fungal symbionts, causing disease and mortality of large numbers of trees (Wood 1982; Bhagwandin 1993; Kamata et al. 2002; Kühnholn et al. 2003; Coyle et al. 2005). A number of hypotheses have been proposed to explain this increase. These include the introduction of beetles into new areas and habitats, effects of climate change on beetle phenology and tree defenses, and changes in fungal symbionts (Kamata et al. 2002; 
Kühnholn et al. 2003). For example, it has been suggested that normally nonpathogenic ambrosia fungi may become pathogenic under conditions of climate change through increasing stress in trees (Kühnholn et al. 2003).

The fungi associated with ambrosia beetles have, until recently, not been considered pathogens of trees. However, during the course of the past 10 years, two striking examples have appeared where the primary fungal symbionts of ambrosia beetles have emerged as serious pathogens, resulting in large-scale mortality of apparently healthy trees. These include the disease known as oak dieback in Asia (Kubono and Ito 2002) and laurel wilt disease in the USA (Fraedrich et al. 2008). In the case of oak dieback in Asia, it was thought that an exotic fungus was introduced and established a relationship with a native ambrosia beetle, Platypus quercivora (Ito and Yamada 1998). Kamata et al. (2002), however, rejected this hypothesis and suggested that a more likely explanation is that increased temperatures due to climate change have lead to an expansion of the geographic range of $P$. quercivora bringing the insect into contact with hosts that are more suitable for brood development and susceptible to its associated ambrosia fungus (Kamata et al. 2002). In the case of laurel wilt in the USA, the exotic ambrosia beetle, Xyloborus glabratus, commonly infests healthy native laurel trees without laying eggs. During these initial infestations, it introduces Raffaellea lauricola which is highly pathogenic to laurels. The beetle then disperses but later returns to lay eggs and establish brood galleries once the fungus has compromised tree defenses (Fraedrich et al. 2008). The ability to kill healthy trees, in this case, is likely due to the fact that $X$. glabratus and its associated fungus $R$. lauricola have not co-evolved with the tree hosts they infest in the USA and that the tree has little in the way of resistance to the fungus.

The emergence of oak die-back in Asia and laurel wilt disease in the southeastern USA has raised concerns that similar problems might be developing elsewhere. Indeed, a number of new tree disease problems have recently been noted in southern Africa and other parts of the world with which ambrosia beetles and their fungi are involved. The ambrosia beetle, Megaplatypus mutatus, for example, kills Populus in South America (where the beetle is native but the tree is not) and Italy (where the tree is native, but the beetle is not) (Alfaro et al. 2007). Likewise, mortality of native Taeberna montanum trees in South Africa has been found to be associated with infestation by an exotic ambrosia beetle, Xylosandrus crassiusculus, which carries A. beaveri in this location (Roux et al. 2010). Interestingly, the exotic ambrosia beetle, X. mutilatus, carries $A$. beaveri in the southeastern US, but in this case, the beetle is limited to stressed, dying or dead material (Stone et al. 2007; Six et al. 2009). The threat to native forests from exotic ambrosia beetles and their fungi cannot be underestimated. Ambrosia beetles and their symbionts are among some of the most easily and commonly introduced forest insects in the world. They are typically minute, buried deep within wood xylem, and thus, are easily transported in timber and wood-based packaging material (Haack 2001; Mireku and Simpson 2002). The relative ease with which these beetles can be transported long distances is complimented by the fact that many of the beetles, as well as their fungi, are polyphagous, increasing their chances of finding suitable hosts once introduced into a new environment. Furthermore, the breeding strategies of ambrosia beetles are highly conducive to establishment. Many ambrosia beetles are inbreeding and so do not face problems with mate location or inbreeding depression, and can potentially start a new population from a single fertilized female (Kirkendall 1993; Normark et al. 1999).

\section{Sirex-fungus-nematode symbioses}

Siricids that attack conifers (Hymenoptera: Siricidae) are obligately associated with fungi in the genus Amylostereum (Basidiomycotina) (Morgan 1968; Slippers et al. 2003). In most cases, the wasp provides transport and protection for the fungus in internal mycangial sacs associated with the ovipositor of adult female wasps and in external mycangial pockets of the larvae (Talbot 1977). The female wasp introduces the fungus into the wood, together with her eggs, after drilling through the 
bark with her saw-like ovipositor. At this point, the wasps also introduce a phytotoxic mucus that affects the defense mechanisms of the tree which is important for the establishment of both the wasp and the fungus (Coutts 1969). Only one genus of Siricidae, Xeris, do not have mycangia, but rather infect wood that has previously been colonized by Amylostereum following attack by other siricids or wounding (Fukuda and Hijii 1997). The fungus is thought to facilitate the tunneling of developing wasp larvae by physically softening the wood by causing white-rot. The larvae are also thought to gain nutritional benefit from the fungus, both indirectly through the decomposition of cellulose into compounds usable by the insects, and directly by ingestion of the fungal hyphae (Madden and Coutts 1979; Kukor and Martin 1983).

Siricids and their mutualistic fungi are parasitized by nematodes in the genus Deladenus (=Beddingia) (Bedding and Akhurst 1978; Bedding and Iede 2005). These nematodes have a bicyclic life cycle. In one phase, they are morphologically adapted to feed on the Amylosterum symbiont (mycetophagous phase), while in the second, they are adapted to penetrate, feed upon, and reproduce in the larvae of the wasps (parasitic phase). Different species of nematodes are obligate on specific Amylostereum species during their mycetophagous phase (Bedding and Akhurst 1978; Bedding and Iede 2005). They infect both male and female siricids, but are only spread by females during egg-laying. The nematodes also infect wasps parasitic on siricids, but their ability, if any, to spread in these insects is not known.

\section{Importance to ecosystems}

Siricids are native to the Northern Hemisphere where most species attack mature, dying, or recently killed trees (Spradbery and Kirk 1978). As such, they contribute to tree succession and the decomposition process. One exception is Sirex noctilio, a Eurasian wasp that frequently attacks living trees, although predominantly those that are severely stressed. This species has rarely been viewed as a serious threat to forests or plantations of pine in its region of origin. In contrast, $S$. noctilio has caused serious damage to pine plantations in the southern hemisphere where it has been accidentally introduced several times (Neumann and Minko 1981; Haugen 1990; Hurley et al. 2007). In the Southern Hemisphere, up to $80 \%$ mortality has been recorded in outbreaks in plantations. The difference in the impact of this insect in areas of introduction compared to in its native range has been attributed to the absence of, or irregular pressure from, natural enemies, the presence of large stands of susceptible hosts that are uniform in age and genetic composition, and wide-scale stress in host trees (either due to poor management, dense planting practices, or natural environmental factors such as drought) (Neumann and Minko 1981; Haugen 1990; Hurley et al. 2007).

\section{Anthropogenic effects}

The movement of wood around the world by humans has resulted in the successful establishment of $S$. noctilio on several continents. The first establishment of this insect and its Amylosterum areolatum symbiont outside its native range was in New Zealand around 1900 (Hurley et al. 2007). The wasp subsequently spread to Australia, various South American countries, South Africa, and, most recently, North America (Hoebeke et al. 2005; Nielsen et al. 2009). Prior to its introduction to North America where the insect is now established in native forests, all introductions were into plantations of exotic pines.

The movement of $S$. noctilio around the world has resulted in a number of changes in wasp behavior, as well as in the wasp-fungus symbiosis. Despite the fact that $S$. noctilio is not a pest in its home range, when it first appeared in Australia the damage in plantations was sufficiently severe to justify a major program to manage the insect (Neumann and Minko 1981; Madden 1988). A key component of this program was biological control using introduced parasitoid wasps and the Sirex- 
specific parasitic nematode, Deladenus siricidicola, strains of which were introduced from various parts of the home range of the wasp (Bedding and Akhurst 1978; Bedding and Iede 2005).

Of all the biological control agents used to manage populations of the wasp, D. siricidicola has been the most fundamental (Bedding and Iede 2005; Hurley et al. 2007), yet efficacy has been variable. For example, in Australia, extensive inoculation programs in the $1980 \mathrm{~s}$ eventually failed when the nematode lost its virulence (Haugen 1990, Haugen and Underdown 1993). The loss of virulence was resolved by introducing a newly isolated strain, Kamona, from Tasmania (Bedding and Iede 2005). However, the Kamona strain was not equally effective in all cases. For example, in South Africa, the expectation was that the nematode would provide a rapid solution to a sizeable outbreak of the wasp that recently occurred in the major pine-growing areas of the country. However, only poor levels of success were achieved (Hurley et al. 2007; 2008). Although the basis of this problem remains to be fully resolved, various factors relating to the symbiosis between the wasp, its fungal associate and its parasitic nematode have emerged. For example, it was found that the genotype of $A$. areolatum on which the Kamona strain of $D$. siricidicola is raised is different to that associated with wild populations of the wasp in South Africa (Slippers et al. 2002; 2003). The Kamona strain of the nematode from Australia grows less effectively on the strain of A. areolatum carried by $S$. noctilio in South Africa under some conditions (BP Hurley, B Slippers, unpublished data) which may account, at least in part, for the low infection rates achieved in that country thus far.

The success of both the wasp-fungus symbiosis and biological control programs for its control using the parasitic nematode depend on a complex suite of environmental conditions (Hurley et al. 2007; 2008). For example, the moisture content of Sirex-infested wood is crucial to the development of $A$. areolatum, and thus, $D$. siricidicola. Therefore, climate will strongly influence the wasp, its symbiont and its biological control agents, each of which will respond in an idiosyncratic manner. As conditions change due to global warming, the relative suitability of an environment for each will also change with subsequent effects on the ability of the wasp to kill trees and also the efficacy of biological control.

Competition with other organisms is also likely to influence the biology of the wasp, itsmutualistic fungus, and its parasites. For example, in South Africa, S. noctilio-infested trees are rapidly colonized by the exotic European bark beetle, Orthotomicus erosus. Orthotomicus erosus carries a symbiotic fungus, $O$. ips, which colonizes the wood. In addition, trees are often colonized by Diplodia pinea, a fungus that is either endophytic in the tree or that is also introduced by the bark beetles (BP Hurley, B Slippers, unpublished data). Competition for resources likely occurs between the $S$. noctilio symbiont, $A$. areolatum on which $D$. siricidicola and the wasp must feed, and the bark beetle fungal symbiont(s) that require(s) the same wood resources for their growth and survival. The outcome of this competition under changing environmental conditions likely influences the relative success of $\mathrm{S}$. noctilio at a given site over time.

The recent invasion of $S$. noctilio in North America presents a very different situation from introductions into the Southern Hemisphere because this is the first area where the wasp has appeared as an exotic where pines are native (Hoebeke et al. 2005; Nielsen et al. 2009). As an exotic in North America, S. noctilio will encounter native siricid wasps, their fungal symbionts, and their natural enemies. It will also encounter bark and ambrosia beetles with their complements of fungi. It is unclear how native wood wasp-fungus-natural enemy and bark- and ambrosia beetlefungus complexes will interact with $S$. noctilio and its fungus, but it is likely that the wasp and its symbiont will compete for resources very differently in these forests than it has in plantations of non-native pines in the Southern Hemisphere, which to a large extent represent an open niche that the wasp has been able to fill. 
Sirex noctilio is an interesting case where we have a symbiosis occurring under multiple unique situations: as a native in native hosts in its native environment, as an exotic in exotic hosts in an exotic environment, and as an exotic in native hosts in an exotic environment. In the various regions where this insect is established, the symbiosis also experiences a variety of climate regimes including winter, summer, and bimodal rain patterns as well as different competitors. This provides us with the unique opportunity to investigate, for one symbiosis, how changes in the environment, whether natural or anthropogenic, can affect outcomes.

\section{Fungus-growing ant-microbe symbiosis}

Ant-fungus symbioses occur among more than 200 described species of ants in the tribe Attini (Hymenoptera) and the fungi (Agaricales: Lepiotaceae, Pterulaceae) they cultivate for food (e.g., Weber 1966; 1972). While several distinct strategies of ant-fungus agriculture occur within this broad form of symbiosis (Schultz and Brady 2008), the leaf-cutting ants (genera Atta and Acromyrmex) have evolved the ability to harvest and use fresh plant material for maintaining their fungus cultivar. Along with two other genera (Trachymyrmex and Sericomyrmex), leafcutting ants practice what has been termed 'higher agriculture'. In higher attine agriculture, the cultivated fungus no longer appears to be able to exist outside the mutualism. These fungi have evolved specialized gongylidia, nutrient-rich hyphal swellings, which are harvested by the ants and used to feed primarily to ant larvae (Chapela et al. 1994; Mueller et al. 2001).

In attine agriculture, there are four microbial symbionts that form an integrated part of the fungusgrowing ant-microbe symbiosis. These include the mutualistic fungus that the ants maintain for food (Möller 1893; Hölldobler and Wilson 1990) and fungi in the genus Escovopsis that parasitize the ants' mutualistic fungus. Escovopsis have been shown to directly target and consume the beneficial fungus (Currie et al. 1999a; Reynolds and Currie 2004) and appear to be specific to attacking fungus-growing ant-associated fungi. They are associated with the majority of fungusgrowing ants, and can incur significant fitness costs to ants in infected nests (Currie 2001; Currie et al. 2003a, Poulsen et al. 2010) and can devastate entire colonies (Currie et al. 1999a; MP, personal observation). In addition to employing behavioral defenses to physically remove Escovopsis from infected garden material (Currie and Stuart 2001; Abramowski et al. 2011), the ants employ defensive mutualists to control Escovopsis. These are Pseudonocardia bacteria (Actinomycetales: Pseudonocardiaceae) (Currie et al. 1999b; Cafaro and Currie 2005) that are maintained on the cuticle of the ant host where they secrete secondary metabolites that strongly inhibit Escovopsis (Currie et al. 2006; Oh et al. 2009; Poulsen et al. 2010; Cafaro et al. 2011). Experiments where Pseudonocardia has been removed have resulted in subsequent Escovopsis infection (Currie et al. 2003a). Likewise, a recent evaluation of the role inhibitory properties of Pseudonocardia play in regulating Escovopsis-induced morbidity (Poulsen et al. 2010) supports the hypothesis that the ants use antibiotics from Pseudonocardia to limit Escovopsis infections.

Despite decades of work on the fungus-growing ant system, recent work has identified two additional symbiont groups. The first is black yeast (Ascomycota; Phialophora) that grows on the same locations on the ant cuticle as Pseudonocardia (Little and Currie 2007) and appears to exploit the fungus-growing ant system by acquiring nutrients from Pseudonocardia thereby reducing its ability to suppress Escovopsis (Little and Currie 2008). Furthermore, nitrogen-fixing bacteria (Klebsiella and Pantoae) are also present within fungus gardens of leafcutting ants. These bacteria fix atmospheric nitrogen in the fungus garden and, as the ants consume the fungus material, the fixed nitrogen becomes incorporated into the ants (Pinto-Tomás et al. 2009).

Fungus-growing ants, the cultivar fungus, the parasites of the fungus, and the defensive Pseudonocardia mutualists have all undergone some degree of co-diversification, and possibly coevolution (Mueller et al. 1998; Currie et al. 2003b; Cafaro et al. 2011). The two best-studied 
mutualistic symbionts, the cultivar and Pseudonocardia, are both vertically transmitted between host-ant generations by default (von Ihering 1898; Autuori 1956; Currie et al. 1999b; Mueller et al. 2001; Fernández-Marín et al. 2004), leading to expectations of patterns of host-mutualist cocladogenesis, which indeed is observed. Despite default horizontal transmission between nests (Currie et al. 1999a), Escovopsis also show some degree of broad-scale congruence with the ants and host cultivars (Currie et al. 2003b). Thus, patterns of phylogenetic congruence between the ants and their associated symbionts are characterized by broadscale phylogenetic matching creating distinct groups of ants and associated symbionts. Within these groupings, switching of symbionts within and between ant species, and genera, appears to be frequent, disrupting strict patterns in lower-level phylogenetic congrunce (Adams et al. 2000; Poulsen et al. 2005; Taerum et al. 2007; Gerardo and Caldera 2007; Mikheyev et al. 2007, Poulsen et al. 2009).

\section{Importance to ecosystems}

Leaf-cutting ants are major herbivores in tropical New World forests and agricultural landscapes (Hölldobler and Wilson 1990). Workers from individual mature Atta leafcutter nests and can harvest more than $200 \mathrm{~kg}$ dry weight of leaf material per year (Wirth et al. 2003), and consequently, they play a major role in nutrient cycling in tropical forests. They may also play an important role in nitrogen cycling due to their association with nitrogen fixing symbiotic bacteria (Pinto-Tomás et al. 2009). In addition, leaf-cutting ant colonies, through deposition of seeds in their dumps, can play a significant role in seedling recruitment during the dry season (Farji-Brener and Ghermandi 2004). Although less is known about the ecological role and impact of the lower attines, at least one study has documented a beneficial effect of these ants in dispersal of seeds from non-myrmecophyte plants (Leal and Oliveira 1998).

\section{Anthropogenic effects}

There has been little focus on anthropogenic effects on fungus-growing ants, likely because the most conspicuous fungus-growers, the leaf-cutting ants, appear to be resilient to the most obvious direct influences of humans on forest ecosystems, deforestation and habitat fragmentation (MayhéNunes and Jaffe 1998). However, studies examining habitat use by fungus-growing ants indicate that human-caused changes in habitat may have significant impacts. Certain genera are plastic in habitat use (lower attine species in the genera Cyphomyrmex, Mycetarotes and Mycetosoritis, and the higher-attine genera Trachymyrmex and Sericomyrmex,), while some genera are highly specific (the lower attine genera Mycetophylax and Mycocepurus) (Mayhé-Nunes and Jaffe 1998). Consequently, different habitats harbor distinct, but overlapping, attine species compositions. As habitats are altered due to logging, clearing for agriculture, or climate change, such alterations are likely to induce changes in ant species composition (cf. Vasconcelos et al. 2008) impacting ant species diversity through either species composition changes and/or species loss.

Ant symbiont communities are expected to follow changes in ant communities. However, some may shift in response to environmental change with subsequent alterations of natural host-mutualist dynamics. This is because, despite default vertical transmission, there is frequent between-colony switching of both the fungal cultivar and Pseudonocardia mutualists. Ecological and geographic range shifts due to climate change may, therefore, result in losses of some symbionts as well exposure to new ones. Similarly, the association with Escovopsis is shaped by host switching within and between ant species, so that changes in ant abundance and community composition has the potential to alter what hosts are available, and hence, alter host-parasite dynamics.

In addition to the direct effects of anthropogenic change on fungus-growing ant species, diversity, abundance, and symbiotic associations, there are several potential indirect effects. Leaf-cutting ants play several major roles in New World tropical forest ecosystems. They harvest large amounts of 
vegetation affecting the demography of individual plants and the structure and composition of the plant community as a whole. Through their fungal gardens, they accelerate the decomposition process, thus shortening nutrient cycling times (Fowler et al. 1989). Studies exploring plant community successional patterns suggest that leaf-cutting ants nests may be focal points for ecosystem renewal and promote increased plant diversity (Fowler 1977; Jonkman 1978). Several vertebrates and many invertebrates are also dependent in one way or another upon the ants and their nests (Weber 1972). Because substrate use differs between species, changes in leaf-cutting ant species distribution will likely affect plant species distributions and nutrient flow (Fowler et al. 1989). Consequently, changes in plant diversity, species abundances, and community composition are expected due to anthropogenic effects on ant distribution. Furthermore, nitrogen fixation by symbionts associated with leaf-cutting ants may play an important role as a nitrogen source in tropical ecosystems (Pinto-Tomás et al. 2009), implying that a reduction or turnover in species composition of ants in an area has the potential to alter nitrogen flow.

\section{Termite-fungus symbioses}

The termite-fungus mutualism occurs between members of the termite subfamily Macrotermitinae (Termitidae) and fungi in the genus Termitomyces (Basidiomycotina) (Aanen and Boomsma 2006). Termite workers build a soil structure within which the colony and symbiotic fungus is housed. In some cases, these structures are entirely below-ground, but for the most complex group (genus Macrotermes), the structures consist of large architecturally complex mounds (Darlington and Dransfield 1987). These mounds act not only to protect the fungal symbiont, but also to protect and defend the termites, and in extreme cases, the mound acts as a form of lung, allowing gas exchange between the colony members and the atmosphere (Turner 2001).

The fungus retains a full sexual cycle with fruiting bodies (mushrooms) that push up through the walls of the mound to erupt above the soil surface. These fruiting bodies produce basidiospores which are dispersed into the environment, often onto the soil surface surrounding the mound (Aanen et al. 2002). In nearly all macrotermitine species, these spores are picked up by foraging workers from a recently established termite colony and taken back to the nest. Within the nest, the spores are mixed with partly-digested dead plant material (wood, leaf litter or grass) to form a fungus comb. The comb is expanded over time and becomes the site of the majority of the digestive activity within the nest and provides food for the entire colony. Termitomyces is able to break down both cellulose and lignin in dead wood, thus the digestion of plant material placed into the comb and its conversion to fungal comb (and respiratory gases) is very close to complete (Ohkuma 2003; Konate et al. 2003). This relationship appears to have evolved in the early Tertiary within African megathermal forest. Subsequently, the mutualist system has colonized Asia and Madagascar, but is absent from the New World, Europe and Australia (Aanen and Eggleton 2005).

\section{Importance to ecosystems}

Fungus-growing termites are distributed in four main broad habitats: rainforest, forest edge, wet savannas and dry savannas and do not penetrate far into drier or colder habitats (Aanen and Eggleton 2005). There is considerable species turnover between these habitats, but with species richness and generic richness declining as rainfall declines (Eggleton 2000). In contrast, the ecological impact of fungus-growing termites is probably hump-shaped with the greatest impact occurring in savannas with intermediate levels of rainfall where they are undoubtedly the most important decomposer organisms (Schuurman 2005). Fungus-growing termites are key ecosystem engineers, strongly affecting a wide range of soil properties and vegetation. They can collect up to $60 \%$ annually of the grass, wood and leaf fall in an area. This acts to reduce fuel loads and fire intensity while simultaneously enriching soil (Jones 1990; LePage et al. 1993). Termites, their fungi, and their mounds, also provide shelter and food for many organisms occurring within and 
around their mounds (Sileshi et al. 2009; Pringle et al. 2010). These include numerous arthropods, as well as many vertebrates including birds, reptiles, aardvarks, chimpanzees and gorillas (Sileshi et al. 2009). Humans also utilize termite mound soil and consume Termitomyces mushrooms (Sileshi et al. 2009).

\section{Anthropogenic effects}

The ecological function of fungus-growing termites is generally less susceptible to anthropogenic conversion of rainforest to derived savannas than are other termitid groups. This is because macrotermitines from surrounding habitats often invade disturbed areas including areas developed for agricultural use where they can become pests (Wood et al. 1980). However, whether this occurs or not depends partly on the species present and partly on how isolated undisturbed habitat blocks are from one another. In southern Cameroon, forest disturbance causes a decline in diversity with no compensating influx of savanna species. In contrast, in some areas where macrotermitines persist after disturbance, they can become the dominant termites. For example, in Malaysia, the forest edge specialist, Macrotermes gilvus, reaches very high densities in oil palm plantations (P. Eggleton, personal observation).

Conversion of natural systems into agricultural land often leads to an increase in the impact of pest fungus-growing termite species, typically savanna-specialists that are likely to have had a long evolutionary association with humans (Wood 1996). These include timber pests, which are found in all habitats, and crop pests, which are particularly prevalent in cleared areas. In Africa, particular pest genera are known to specialize on different parts of the crop plant, including roots, stem and leaves (Wood, 1996).

Because fungus-growing termites can be pests, this has led to efforts to control them in some situations. Organochlorine compounds were used commonly until banned due to adverse environmental effects. The focus now is on the use of fungicides that target the Termitomyces symbiont (Rouland-Lefevre and Mora 2002). However, the control of fungus-growing termites may negatively affect humans and non-target organisms, soil productivity and ecosystem services, and traditional human cultural linkages to the termites and Termitomyces (Sileshi et al. 2009).

The ecological consequences of forest disturbance and fragmentation are clear for termites as a whole: functional diversity is reduced considerably in fragmented and disturbed rainforest areas and diversity is lower in savannas than in rainforests (Davies et al. 2003). This applies particularly to soil-feeding termites, which provide essential ecosystem services in the soil (Donovan et al. 2001). However, this pattern is not so evident in fungus-growers, as they show greater resilience and complementary species turnover than most other termite groups. The considerable decompositional services that they provide are, therefore, less attenuated across a disturbance gradient and/or a forest - savanna one (Wood and Sands 1978).

Climate change is predicted to make most tropical environments hotter and drier. This will likely reduce macrotermitine diversity, but potentially increase the relative ecological impact of the fungus-termite mutualism, overall. Drier areas will have fewer free-living fungal decomposers, and so Termitomyces is likely to be at a selective advantage. This advantage, however, will only occur where reductions in rainfall are not too great, as areas converted to semi-deserts or deserts will be too dry to support fungus-growing termites and their fungi. Besides effects on soils and decomposition, cascading effects of these changes are expected to affect the may organisms that habitually co-exist with macrotermitines (Pringle et al. 2010). 


\section{Hemiptera-bacteria symbioses}

Most hemipterans possess bacterial endosymbionts that are either obligate or facultative for survival and reproduction (primary and secondary endosymbionts, respectively) (Buchner 1965; Baumann et al. 2005; Moran et al. 2008; Oliver et al. 2010). Many primary endosymbionts are enclosed in host-derived vesicles (bacteriocytes) and are widespread in hemipterans that feed on nutrientlimited diets, such as plant sap (Buchner 1965; Baumann et al. 2005). The benefit of primary symbionts to their hosts is thought to be nutritional and has been extensively studied in the bacterial symbiont Buchnera and its aphid (Aphidae) hosts (Baumann et al. 1995; Shigenobu et al. 2000; Sandström et al. 2001; Moran et al. 2005).

In contrast to primary symbionts, secondary symbionts are not harbored within specialized cells, but rather occur within their host's hemolymph, glands, gut tissue, sheath cells surrounding the primary symbionts's bacteriocytes, or syncytial tissue surrounding bacteriocytes (Buchner 1965; Fukatsu and Nikoh 1998; Fukatsu et al. 2000; Subandiyah et al. 2000; Mira and Moran 2002). The effect of secondary symbionts on their insect hosts are not well understood (Baumann et al. 2000; Baumann 2005); however, in the Acyrthosiphon pisum (Hemiptera: Aphidae) system, they are known to exert a number of effects including resistance to parasitoids (Oliver et al. 2003; 2005; Ferrari et al. 2004; Vorburger et al. 2010) and fungal entomopathogens (Ferrari et al. 2004, Scarborough et al. 2005), thermal tolerance (Chen et al. 2000; Montllor et al. 2002; Russell and Moran 2006), and host plant specialization (Tsuchida et al. 2004).

\section{Importance to ecosystems}

The order Hemiptera is one of the most ecologically diverse orders of all insects (Gaston 1991; Cassis and Gross 1995; Moir and Brennan 2007). In forest habitats, Hemiptera occupy multiple trophic levels and microenvironments. The vast majority of hemipteran species are known to be plant feeders; however, carnivorous, omnivorous, and fungivorous species are also common (Moir and Brennan 2007). Forest hemipterans occupy multiple forest microhabitats including the understory (soil, leaf litter, roots, under logs and rocks) and the overstory (colonizing a wide variety of plant micro-habitats including leaves, stems, petioles, buds, bark, flowers, and galls) (Schowalter and Zhang 2005; Moir and Brennan 2007).

Hemipterans play important roles in forest foodwebs. They provide abundant prey for many invertebrate and vertebrate forest predators (Moir and Brennan 2007). Additionally, some herbivorous species exhibit outbreak dynamics in forest ecosystems and consequently influence plant community composition and structure (Hill 1947; White 1971; Morgan 1984; Yukawa 1984; Wylie and Peters 1993) and forest successional trajectories and disturbance dynamics (Moir and Brennan 2007).

\section{Anthropogenic effects}

Numerous hemipterans have become invasive pests in natural forests, plantations, urban forests, and agriculture because of accidental human introductions. The potential for successful establishment of an exotic organism is typically attributed to propagule pressure, ability to survive and increase from low densities, and intrinsic as well as extrinsic factors that determine population abundance (Williamson 1996). In the case of several invasive hemipterans, secondary bacterial endosymbionts have also played important roles in increasing the likelihood of their host's success in new environments by modulating their interactions with natural enemies (Oliver et al. 2003; Oliver et al. 2006; Hansen et al. 2007; Vorburger et al. 2010) and inducing thermal tolerance (Chen et al. 2000; Montllor et al. 2002; Russell and Moran 2006; Dunbar et al. 2007; Harmon et al. 2009). 
Microbial symbionts can influence biological control efforts to manage invasive hemipterans. For example, the pea aphid, A. pisum, a native to Eurasia, was first detected in North America in the $1870 \mathrm{~s}$ (Harper et al. 1978). In the $1960 \mathrm{~s}$, a parasitoid wasp, Aphidius ervi, was released to control the aphid (Halfhill et al. 1972; Mackauer and Campbell 1972; Angalet and Fuester 1977). It was soon noted that different clonal lines of A. pisum varied in susceptibility to the parasitoid (Henter and Via 1995). This variation was initially thought to be caused by genetic variation in the aphid host's genotype (Henter and Via 1995); however, subsequent laboratory studies revealed that secondary endosymbionts (Serratia symbiotica, Hamiltonella defense and Regiella insecticola) may in fact be the primary factors conferring resistance to the wasp (Oliver et al. 2003; Vorburger et al. 2010). The genetic mechanism involved in $H$. defensa induced-resistance, for the strain that confers the greatest resistance toward the parasitoid, is linked to a lysogenic lambdoid bacteriophage, APSE (Moran et al. 2005; Degnan and Moran 2008, Degnan et al. 2009; Oliver et al. 2009).

Indirect evidence of symbiont-induced resistance toward a parasitoid has been found in the exotic red gum lerp psyllid, Glycaspis brimblecombei (Hansen et al. 2007). This psyllid invaded California from Australia where it became well established on an important introduced urban forest tree, Eucalyptus camaldulensis (Paine et al. 2000). In 2001, the parasitoid, Psyllaphaegus bliteus, was released to control the psyllid (Paine and Millar 2002). This parasitoid is a specialist of $G$. brimblecombei in its native range in Australia where it is important in regulating psyllid populations (Dahlsten et al. 2005). After release, successful establishment and population regulation by $P$. bliteus was found in some psyllid populations, but not in others (Dahlsten et al. 2005). A subsequent survey found that infection frequencies of a secondary endosymbont (Arsenophonus sp.), varies dramatically among psyllid populations, and is significantly related to wasp parasitism pressure. Collectively, these results suggest that resistance is induced by the symbiont (Hansen et al. 2007). Interestingly, the psyllid's Arsenophonus secondary endosymbiont encodes for an APSE-like phage gene within the bacterium's chromosome which shares $>90 \%$ similarity to the APSE polymerase gene from the lytic phage associated with $H$. defensa-induced resistance in the pea aphid (Hansen $e t$ al. 2007). This phage is incorporated into the chromosome of Arsenophonus; however, and does not appear to be lysogenic or lytic (Hansen et al. unpublished data).

Insects have restricted thermal tolerances. Therefore, a very important factor for the establishment of an exotic species is climate matching. In A. pisum, it has been found that S. symbiotica-infected clones have higher fitness relative to un-infected clones during heat shock treatments in the lab (Chen et al. 2000; Montllor et al. 2002; Russell and Moran 2006). It has also been found that a mutation in the promoter region of a heat-shock gene in A. pisum's primary endosymbiont (Buchnera) can influence heat tolerance (Dunbar et al. 2007). Using field cages, Harmon et al. (2009) found that aphids harboring the active Buchnera promoter and S. symbiotica exhibited greater population increase under hot conditions relative to aphids harboring the impaired Buchnera promoter and which were uninfected with S. symbiotica.

Field studies have found that infection frequencies of $A$. pisum by $S$. symbiotica can reach up to $80 \%$ in warm habitats such as in the Central Valley of California where the insects have become major pests (Chen and Purcell 1997). Moreover, S. symbiotica strains obtained from colder environments conferred less of a fitness benefit in the lab during heat shock treatments relative to a strain from a warmer location (Arizona) (Russell and Moran 2006). Nevertheless, all strains conferred higher fitness to their hosts during heat shock relative to un-infected $\mathrm{A}$. pisum clones (Russell and Moran 2006). These results suggest that the ability of the pea aphid to tolerate a broad range of thermal conditions in its invasive range is mediated and supported by its endosymbionts, contributing to its establishment and spread. 
The introduction of exotic hemipterans has had serious implications for both native and exotic plantation trees and urban forests around the world, typically through feeding damage by these often prolific breeders. Coversely, the introduction of exotic crops and trees has provided opportunities for native hemipterans that were not previously pests to become pests as they switch onto new and economically important host plants. One reason why some native hemipterans become major pests on exotic plants is because of their intimate interactions with bacterial endosymbionts (Hosokawa et al. 2007; Hansen et al. 2008; Bressan et al. 2009), which can mediate their success on the new host or even act as pathogens. While examples of such switches are rare for forest systems, examples from agriculture abound. Such effects are likely to increase as plantation and urban forests composed of exotic species continue to expand worldwide.

One example of where symbionts have supported a host shift by a native hempiteran onto an exotic plant has been observed in Japan. In this case, two geographically isolated plataspid stinkbugs, Megacoptera punctatissima and M. cribraria, which feed on two native leguminous vine host plants, Pueraria lobata and P. montana, respectively. Each stinkbug harbors an obligate primary endosymbiont, Ishikawaella capsulata, which is vertically transmitted externally as a 'symbiont capsule' under the egg mass. Once nymphs hatch they orally acquire the symbiont from the capsule. Hosokawa et al. (2007) found that when they switched egg mass capsules between the species their performance on soya bean plants and pea pods were completely reversed. These results suggest that the pest status of $M$. punctatissima is determined solely by its primary symbiont and not by insect genotype.

Human introductions of exotic plants can also influence vectoring of disease by native hemipteran insects. Interestingly, bacterial endosymbionts can also sometimes act as pathogens when injected by the insect into a plant. The syndrome 'basses richesses' (SBR) is a phloem-restricted disease of sugar beet (Beta vulgaris) in eastern France, and is associated with a SBR bacterium that is vectored by the planthopper, Pentastiridius leporinus (Bressan et al. 2009). Additionally, a closely related bacterium, Phlomobacter fragariae, is the main causal agent of marginal chlorosis disease of strawberry in western France and is vectored by the cixiid planthopper, Cixius wagneri. Both bacteria reside within the Arsenophonus clade (Bressan et al. 2009; Nováková et al. 2009). Interestingly, Arsenophonus species are primarily known as insect endosymbionts and not as plant pathogens (Gherna et al. 1991; Hansen et al. 2007; Allen et al. 2007; Trowbridge et al. 2006; Perotti et al. 2007). The plant pathogen, SBR, appears to be intimately associated with its insect host since it is vertically transmitted, is maintained throughout all planthopper life stages, and is found in planthopper gonads, salivary glands, gut, bacteriomes, and malpighian tubules (Bressan et al. 2009). Whether or not the bacterium increases its insect vector's fitness on diseased crop plants remains to be determined. Another bacterium with a duel role as an endosymbiont and plant pathogen is Liberibacter psyllaurous, which is harbored by the tomato psyllid Bactericerca cockerelli (Hansen et al. 2008).

\section{Topics for future research}

\section{Climate change}

Climate change will increasingly affect symbioses including mutualisms, and unlike for most other anthropogenic effects, changes in on-the-ground policy or management, or the implementation of strategic measures to alleviate impacts, in most cases, cannot be used effectively to lessen its impact. With emissions of carbon dioxide and other greenhouse gases continuing to increase, effects will not only continue but become increasingly severe. 
Mutualisms, particularly those occurring between ectotherms such as those showcased in this review, are particularly sensitive to changes in temperature. They retain stability and function under one set of conditions but may decouple as conditions shift beyond the particular thresholds of one or more partners. Such effects are not trivial. Effects on key mutualisms will likely ramify throughout ecosystems with as-of-yet unknown outcomes. In order to better understand how climate change will affect ecosystems, we will need to incorporate these critical interactions into the conceptual and predictive models we use to guide our research and conservation goals. For example, phenological models for the host are often used to predict range expansions and contractions under various climate scenarios. However, the use of phenological models for both hosts and symbionts in tandem will generate more accurate predictions of such range changes by detecting where critical symbionts may become marginalized or lost. While the use of host and symbiont models together will be a significant step forward in understanding the response of mutualisms to warming trends, this approach does not incorporate the potential for the host or its symbionts to adapt to rapid warming or to switch partners as thermal regimes change. To understand if adaptation or partner switching is likely, we will also need to begin to assess levels of heritable variability and phenotypic plasticity to different scenarios, as well as experimentally challenge hosts and symbionts with potential new partners and to increased temperatures in controlled experiments.

Forest insect-microbe mutualisms provide some of the most amenable and appropriate systems to study for effects of climate change on mutualisms. They have significant impacts on the ecosystems within which they exist and information on their response to changing temperature regimes is needed to predict future conditions in our forests. The organisms involved are small in size and rapid to respond to even small changes in environmental conditions. Furthermore, forests often span significant latitudinal and elevational gradients allowing us to study particular symbioses under different environmental conditions and in areas undergoing differing degrees of climate change.

\section{Exotic introductions}

The introduction of exotic insects is one of the biggest threats to forest ecosystems. The movement of wood and wood products is one of the biggest contributors to the movement of exotic insects globally. Wood-boring insects feed on nutritionally poor substrates and depend on microbial endoor ectosymbionts to aid in breaking down cellulose and lignin, to provide sterols, vitamins, and other critical compounds, or to concentrate or fix nitrogen. While many of these microbial partners pose no threat, some are pathogens and exhibit greater pathogenicity in new environments and host trees than in their native range. Therefore, not only the effects of the exotic insect must be considered when attempting to predict negative impacts of establishment, but also the impact their symbionts may have when introduced into tree hosts with which they have not coevolved. Unfortunately, it can seldom be predicted which symbionts will exhibit virulence in novel tree hosts. Currently, it is only after introduction that such effects become apparent. Therefore, it would be advantageous to test for virulence of microbial partners of wood-inhabiting insects, as these are known to be of high risk for introduction (USDA 1994) Such information would be valuable in prioritizing both regulatory responses to avoid introduction by identifying the insect-microbe partnerships that are most likely to have substantive negative impacts on native trees.

Other needed research involving exotic forest insects and symbionts involves investigations into the degree of flexibility and fidelity that occurs among partners. Some mutualisms are relatively flexible, with partner shifts occurring commonly, albeit usually among taxonomically related groups. In the case of exotic insects, the acquisition of new symbionts may alter the range of tree hosts that can be used by the host or its ability to colonize particular substrates. Additionally, symbionts of exotic insects may be acquired by native insects which may result in exposure of a greater range of native trees to these symbionts, some of which may be phytopathogens. 


\section{Direct human impacts on forest structure and compositions}

The direct effects of humans on forested landscapes will continue to affect critical mutualisms. The human population on Earth continues to increase and with this increase comes increased demands on ecosystems for space and resources. Fragmentation and conversion forest to agricultural lands continues at a rapid pace, particularly in developing countries. However, even in areas where the rate of deforestation is significantly less or where forests are actually increasing in extent, selective cutting, conversion from one forest type to another, alteration of genetic structure due to replanting with off-site seeds or seedlings, and fire suppression, continue to alter forests, their function and resilience, and organismal diversity. Unlike climate change, an understanding of the effects of various anthropogenic effects can be used to develop strategic approaches and policies to alleviate or reverse many of these negative impacts. However, with ever increasing demands on forests the ability to implement such measures will become increasingly difficult. An understanding of how various human activities affect individual organisms and their interactions with others (particularly mutualisms) will be key to developing the best, most effective measures to maintain functional, resilient forest and savanna ecosystems.

\section{Conclusions}

Forests and savannas have been heavily impacted by human activities including deforestation, fragmentation, loss of biodiversity, anthropogenic climate change, introduction of exotics, and alterations in forest composition, structure and disturbance regimes. Concern over these effects has given rise to a large number of studies focusing on impacts on individual species or on biotic community structure and composition. Much less common have been studies of impacts on critical interactions, especially mutualisms. Mutualisms, in general, have been seriously understudied until recent years (Janson et al. 2009). However, in the last two decades, studies on these interactions have virtually exploded in number, resulting in a new appreciation for their importance as major drivers of ecosystem process and function (Bronstein 1994).

Most organisms are involved in at least one mutualism, and many in several. Mutualisms facilitate the ability of partners to exploit otherwise marginal or inaccessible habitats and resources, and determine the ecological boundaries of many organisms (Janson et al. 2009). When perturbation or change disrupts, enhances or introduces new organisms into a mutualism, the outcome and stability of the original partnership(s) are altered as are the effects of the symbiosis on the community and ecosystem as a whole (Six 2009). This potential for human-induced environmental change to alter or decouple mutualisms is an area of critical need for research in ecology and evolution (Kiers et al. 2010).

In this paper, using examples from microbial-insect mutualisms in forest and savanna settings, we have tried to showcase how varied and complex the responses of mutualisms can be to an equally varied set of anthropogenic influences. In the process, we hope to have convincingly argued for the need to focus on community interactions, particularly mutualisms, when investigating the effects of anthropogenic change on natural systems. Researchers must be cognizant that many alterations in behaviors and distributions of organisms that are observed to occur in response to anthropogenic activities are likely being mediated by mutualists and other symbionts. Therefore, whether the goal is to understand the basic ecology of an organism, its response to anthropogenic or other types of environmental change, or to manage it as a pest, we argue that it is necessary to consider effects on hosts and symbionts in tandem. Additionally, it is clear that few mutualisms are being affecting by only a single anthropogenic factor, but rather most are being affected by multiple, often interacting, factors, adding an additional level of complexity that must be addressed. 


\section{Acknowledgements}

This paper arose from a symposium on anthropogenic effects on insect-microbial symbioses at the International Congress of Entomology held in Durban, South Africa in 2008. JR, BS, and MJW appreciate the financial support of the Department of Science and Technology/National Research Foundation Centre of Excellence in Tree Health Biotechnology, University of Pretoria, Pretoria, South Africa. MP was supported by The Carlsberg Foundation. We appreciate the comments of Ryan Bracewell, Edie Dooley and Tracy Dahl on a previous version of the manuscript.

\section{References}

Aanen DK, Boomsma JJ (2006) Social-insect fungus farming. Curr Biol 16:R1014-R1016

Aanen DK, Eggleton P (2005) Fungus-growing termites originated in African rain forest. Curr Biol $15: 851-855$

Aanen DK, Eggleton P, Rouland-Lefevre C, Guldberg-Frøslev T, Rosendahl S, Boomsma JJ (2002) The evolution of fungus-growing termites and their mutualistic fungal symbionts. PNAS 99:1488714892

Abramowski D, Currie CR, Poulsen M (2011) Caste specialization in behavioral defenses against fungus garden parasites in Acromyrmex octospinosus leaf-cutting ants. Insect Soc 58:65-75

Adams AS, Six DL (2006) Temporal variation in mycophagy and prevalence of fungi associated with developmental stages of the mountain pine beetle, Dendroctonus ponderosae (Coleoptera: Scolytinae, Curculionidae). Environ Entomol 36:64-72

Adams AS, Six DL (2008) Detection of host habitat by parasitoids using cues associated with mycangial fungi of the mountain pine beetle, Dendroctonus ponderosae. Can Entomol 140:124-127

Adams RMM, Mueller UG, Holloway AK, Green AM, Narozniak J (2000) Garden sharing and garden stealing in fungus-growing ants. Naturwissenschaften 87:491-493

Aguilar R, Ashworth L, Galetto L, Aizen MA (2006) Plant reproductive susceptibility to habitat fragmentation: Review and synthesis through meta-analysis. Ecol Lett 9:968-980

Alfaro RI, Humble LM, Gonzalez P, Villaverde R, Allegro G (2007) The threat of the ambrosia beetle Megaplatypus mutatus (Chapuis) (=Platypus mutatus Chapuis) to world poplar resources. Forestry 80:471-479

Allen JM, Reed DL, Perotti MA, Braig HR (2007) Evolutionary relationships of "Candidatus Riesia spp." endosymbiotic Enterobacteriaceae living within hematophagous primate lice. Appl Environ Microbiol 73:1659-1664

Amman GD (1973) Population changes of the mountain pine beetle in relation to elevation. Environ Entomol 2:541-548

Angalet GW, Fuester R (1977) The Aphidius parasites of the pea aphid Acyrthosiphon pisum in the eastern half of the United States. Ann Entomol Soc Am 70:87-96 
Autuori M (1956) La fondation de sociétés chez les fourmis champignonnistes du genre "Atta". In: Autuori M, Bénassy MP, Benoit J (eds) L'instinct dans le comportement des animaux et de l'homme. J. Masson et Cie, Paris, pp 77-104

Ayres MP, Wilkens RT, Ruel JJ (2000) Nitrogen budgets of phloem-feeding bark beetles with and without symbiotic fungi. Ecology 81:2198-2210

Baker AC (2003) Flexibility and specificity in coral-algal symbiosis: diversity, ecology, and biogeography of Symbiodinium. Ann Rev Ecol Evol Syst 34:661-689

Batra LR (1967) Ambrosia fungi: a taxonomic revision and nutritional studies of some species. Mycologia 59:967-1017

Baumann P (2005) Biology of bacteriocyte-associated endosymbionts of plant sap-sucking insects. Annu Rev Microbiol 59:155-189

Baumann P, Baumann L, Lai C-Y, Rouhbakhsh D, Moran NA (1995) Genetics, physiology, and evolutionary relationships of the genus Buchnera: intracellular symbionts of aphids. Annu Rev Microbiol 49:55-94

Baumann P, Moran NA, Baumann L (2000) Bacteriocyte-associated endosymbionts of insects. In: Workin MD (ed) The prokaryotes. Springer, New York, pp 403-438

Beaver RA (1989) Insect-fungus relationships in the bark and ambrosia beetles. In: Wilding N, Collins NM, Hammond PM, Webber JF (eds) Insect-fungus interactions. Academic, London, pp $121-143$

Beaver RA, Loyttyniemi K (1985) Bark and ambrosia beetles of Zambia. Rev Zool Afr 99:63-85

Bedding RA, Akhurst RJ (1978) Geographical distribution and host preferences of Deladenus species (Nematoda: Neotylenchidae) parasitic in siricid woodwasps and associated hymenopterous parasitoids. Nematologica 24:286-294

Bedding RA, Iede ET (2005) Application of Beddingia siricidicola for Sirex woodwasp control. In: Grewal PS, Ehlers R, Shapiro-Ilan DI (eds) Nematodes as biocontrol agents. CAB International, UK, pp 385-400

Bentz BJ, Schen-Lagenheim G (2007) The mountain pine beetle and whitebark pine walz: Has the music changed? In: Goheen EM, Sniezko RA (eds.) Proc. conference on whitebark pine: a pacific coast perspective. pp. 43-50. R6-NR-FHP-2007-01

Bentz BJ, Six DL (2006) Ergosterol content of four fungal symbionts associated with Dendroctonus ponderosae and D. rufipennis (Coleoptera: Curculionidae, Scolytinae). Ann Entomol Soc Am 99:189-194

Bhagwandin HO (1993) The shothole borer: an ambrosia beetle of concern for chestnut orcharding in the Pacific Northwest. Northern Nut Growers Assn Ann Rep 84:168-177

Blackwell M, Jones K (1997) Taxonomic diversity and interactions of insect associated Ascomycetes. Biodivers Conserv 6:689-699 
Bleiker K, Six DL (2007) Dietary benefits of fungal associates to an eruptive herbivore: potential implications of multiple associates on host population dynamics. Environ Entomol 36:1384-1396

Bleiker K, Six DL (2008) Competition and coexistence in a multipartner mutualism: interactions between two fungal symbionts of the mountain pine beetle in beetle-attacked trees. Microb Ecol 57:191-202

Boone CK, Six DL, Zheng Y, Raffa KF (2008) Parasitoids and dipteran predators exploit volatiles from microbial symbionts to locate bark beetles. Environ Entomol 37:150-161

Boucher DH, James S, Keeler KH (1982) The ecology of mutualism. Annu Rev Ecol Syst 13:315347

Brasier C (2001) Rapid evolution of introduced species via interspecific hybridization. Bioscience 51:123-133

Bressan A, Sémétey O, Arneodo J, Lherminier J, Boudon-Padieu E (2009) Vector Transmission of a plant-pathogenic bacterium in the Arsenophonus clade sharing ecological traits with facultative insect endosymbionts. Phytopathol 99:1289-1296

Bridges R (1983) Mycangial fungi of Dendroctonus frontalis (Coleoptera: Scolytidae) and their relationship to beetle population trends. Environ Entomol 12:858-861

Bronstein J (1994) Our current understanding of mutualism. Quart Rev Biol 69:31-51

Buchner P (1965) Endosymbiosis of animals with plant microorganisms. Interscience Publishers Inc., New York

Cafaro MJ, Currie CR (2005) Phylogenetic analysis of mutualistic filamentous bacteria associated with fungus-growing ants. Can J Microbiol 51:441-446

Cafaro MJ, Poulsen M, Little AEF, Price SL, Gerardo NM, Wong B, Stuart AE, Larget B, Currie CR (2011) Specificity in the symbiotic association between Fungus-growing ants and protective Pseudonocardia bacteria. doi:10.1098/rspb.2010.2118

Carlile MJ, Watkinson SC, Gooday GW (2001) The fungi. Academic

Carroll AL, Taylor SW, Regniere J, Safryanyik L (2004) Effects of climate change on range expansion by the mountain pine beetle in British Columbia. In: Proceedings mountain pine beetle symposium: challenges and solutions. pp. 223-232. Kelowna, British Columbia, Canada. Pacific Forestry Centre Information Report BC-X-399

Cassis G, Gross GF (1995) Hemiptera: heteroptera (Coleorrhyncha to Cimicomorpha). In: Zoological catalogue of Australia, vol 27.3A. CSIRO, Melbourne p 752

Chapela IH, Rehner SA, Schultz TR, Mueller UG (1994) Evolutionary history of the symbiosis between fungus-growing ants and their fungi. Science 266:1691-1694

Chen DQ, Purcell AH (1997) Occurrence and transmission of facultative endosymbionts in aphids.

Curr Microbiol 34:220-225 
Chen D, Montllor CB, Purcell AH (2000) Fitness effects of two facultative endosymbiontic bacterial on the pea aphid, Acyrthosiphon pisum, and the blue alfalfa aphid, A. kodoi. Entomol Exp Appl 95:315-323

Coppedge BR, Stephen FM, Felton GW (1995) Variation in female southern pine beetle size and lipid content in relation to fungal associates. Can Entomol 127:145-154

Costanza R (1997) The value of the world's ecosystem services and national capital. Nature 387:253-260

Coutts MP (1969) The mechanism of pathogenicity of Sirex noctilio on Pinus radiata II. Effects of S. noctilio mucus. Aust J Biol Sci 22:1153-1161

Coyle DR, Booth DC, Wallace MS (2005) Ambrosia beetle (Coleoptera: Scolytidae) species, flight, and attack on living eastern cottonwood trees. J Econ Entomol 98:2049-2057

Currie CR (2001) Prevalence and impact of a virulent parasite on a tripartite mutualism. Oecologia 128:99-106

Currie CR, Stuart AE (2001) Weeding and grooming of pathogens in agriculture by ants. Proc R Soc Lond B 268:1033-1039

Currie CR, Mueller UG, Malloch D (1999a) The agricultural pathology of ant fungus gardens. PNAS 96:7998-8002

Currie CR, Scott JA, Summerbell RC, Malloch D (1999b) Fungus-growing ants use antibioticproducing bacteria to control garden parasites. Nature 398:701-704

Currie CR, Bot ANM, Boomsma JJ (2003a) Experimental evidence of a tripartite mutualism: bacteria protect ant fungal gardens from specialized parasites. Oikos 101:91-102

Currie CR, Wong B, Stuart A, Schultz T, Rehner S, Mueller U, Sung G, Spatafora J, Straus N (2003b) Ancient tripartite coevolution in the attine ant-microbe symbiosis. Science 299:386-388

Currie CR, Poulsen M, Mendenhall J, Boomsma JJ, Billen J (2006) Coevolved crypts and exocrine glands support mutualistic bacteria in fungus-growing ants. Science 311:81-83

Cushman SA (2006) Effects of habitat loss and fragmentation on amphibians: a review and prospectus. Biol Conserv 128:231-240

Dahlsten DL, Daane KM, Paine TD, Sime KR, Lawson AB, Rowney DL, Roltsch WJ, Andrews JW Jr, Kabashima JN, Shaw DA, Robb KL, Downer JA, Geisel PM, Chaney WE, Ingels CA, Varela LG, Bianchi ML, Taylor G (2005) Imported parasitic wasp helps control red gum lerp psyllid. Cal Agr 4:229-234

Dale VH, Joyce LA, McNulty S, Neilson NP, Ayres MP, Flannagan MD, Hanson PJ, Irland LC, Lugo AE, Petersen CJ, Simberloff D, Swanson FJ, Stocks BJ, Wotton BM (2001) Climate change and forest disturbances. Bioscience 51:723-734

Darlington JPEC, Dransfield RD (1987) Size relationships in nest populations and mound parameters in the termite Macrotermes-Michaelseni in Kenya. Insect Soc 34:165-180 
Davies RG, Eggleton P, Jones DT, Gathorne-Hardy FJ, Hernandez LM (2003) Evolution of termite functional diversity: analysis and synthesis of local ecological and regional influences on local species richness. J Biogeogr 30:847-877

Davis AJ, Lawton JH, Shorrocks B, Jenkinson LS (1998) Individualistic species responses invalidate simple physiological models of community dynamics under global environmental change. J Anim Ecol 67:600-612

Degnan PH, Moran NA (2008) Diverse phage-encoded toxins in a protective insect endosymbiont. Appl Environ Microbiol 74:6782-6791

Degnan PH, Yu Y, Sisneros N, Wing RA, Moran NA (2009) Hamiltonella defensa, genome evolution of protective bacterial endosymbiont from pathogenic ancestors. PNAS 106:9063-9068

Del-Claro K, Torezan-Silingardi HM (2009) Insect-plant interactions: new pathways to a better comprehension of ecological communities in neotropical savannas. Neotrop Entomol 38:159-164

Donovan SE, Eggleton P, Dubbin WE, Batchelder M, Dibog L (2001) The effect of a soil-feeding termite, Cubitermes fungifaber (Isoptera: Termitidae) on soil properties: termites may be an important source of soil microhabitat heterogeneity in tropical forests. Pedobiologia 45:1-11

Douglas AE (1994) Symbiotic interactions. Oxford University Press, UK

Dunbar HE, Wilson AC, Ferguson NR, Moran NA (2007) Aphid thermal tolerance is governed by a point mutation in bacterial symbionts. PLoS Biol 5:e96

Eggleton P (2000) Global patterns of termite diversity. In: Abe T, Higashi M, Bignell D (eds) Termites: evolution, sociality, symbioses, Ecology. Kluwer, Dordrecht, pp 25-52

Erasmus BFN, Van Jaarsveld AS, Chown SL, Kshatriya M, Wessels KJ (2002) Vulnerability of South African animal taxa to climate change. Glob Chang Biol 8:679-693

Farji-Brener AG, Ghermandi L (2004) Seedling recruitment in a semi-arid Patagonian steppe: facilitative effects of refuse dumps of leaf-cutting ants. J Veg Sci 15:823-830

Fernández-Marín H, Zimmerman JK, Wcislo WT (2004) Ecological traits and evolutionary sequence of nest establishment in fungus-growing ants (Hymenoptera, Formicidae, Attini). Biol J Linn Soc 81:39-48

Ferrari J, Darby AC, Daniell TJ, Godfray CJ, Douglas AE (2004) Linking the bacterial community in pea aphids with host-plant use and natural enemy resistance. Ecol Entomol 29:60-65

Fowler HG (1977) Some factors influencing colony spacing and survival in the grass-cutting ant, Acromyrmex landolti fracticornis (Forel) (Hymenoptera: Formicidae), in Paraguay. Rev Biol Trop 25:89-99

Fowler HG, Pagani MI, Da Silva OA, Forti LC, Da Silva VP, De Vasconcelos HL (1989) A pest is a pest is a pest? The dilemma of neotropical leaf-cutting ants: keystone taxa of natural ecosystems. Environ Manag 13:671-675 
Fraedrich SW, Harrington TC, Rabaglia RJ, Ulyshen MD, Mayfield AE, Hanula JL, Eickwort JM, Miller DR (2008) A fungal symbiont of the redbay ambrosia beetle causes a lethal wilt in redbay and other Lauraceae in the southeastern United States. Plant Dis 92:215-224

Fukatsu T, Nikoh N (1998) Two intracellular symbiotic bacteria from the mulberry psyllid Anomonerura mori (Insecta, Homoptera). Appl Environ Microbiol 64:3599-3606

Fukatsu T, Nikoh N, Kawai R, Koga R (2000) The secondary endosymbiotic bacterium of the pea aphid Acyrthosiphon pisum (Insecta: Homoptera). Appl Environ Microbiol 66:2748-2758

Fukuda H, Hijii N (1997) Reproductive strategy of a woodwasp with no fungal symbionts, Xeris spectrum (Hymenoptera: Siricidae). Oecologia 112:551-556

Fuller JL, Foster DR, McLachlan JS, Drake N (1998) Impact of human activity on regional forest composition and dynamics in central New England. Ecosystems 1:76-95

Gaston K (1991) The magnitude of global insect species richness. V5: 283-296

Gerardo NM, Caldera EJ (2007) Labile associations between fungus-growing Apterostigma ant cultivars and their garden parasites. Int Soc Microb Ecol J 1:373-384

Gherna RL, Werren JH, Weisburg W, Cote R, Woese CR, Mandelco L, Brenner DJ (1991) Arsenophonus nasoniae gen. nov., sp. nov., the causative agent of the son-killer trait in the parasitic wasp Nasonia vitripennis. Int J Syst Bacteriol 41:563-565

Goldhammer DS, Stephen FM, Paine TD (1990) The effect of the fungi Ceratocystis minor (Hedgecock) Hunt var. barrasii Taylor, and SJB 122 on the reproduction of the southern pine beetle, Dendroctonus frontalis Zimmermann (Coleoptera: Scolytidae). Can Entomol 122:407-418

Haack RA (2001) Intercepted Scolytidae (Coleoptera) at United States ports of entry: 1985-2000. Integr Pest Manag Rev 6:253-282

Halfhill JE, Featherson PE, Dicke AG (1972) History of Praon and Aphidius parasites of the pea aphid in the Pacific Northwest. Environ Entomol 1:402-405

Hansen AK, Jeong G, Paine TD, Stouthamer R (2007) Frequency of secondary symbiont infection in an invasive psyllid relates to parasitism pressure on a geographic scale in California. Appl Environ Microbiol 73:7531-7535

Hansen AK, Trumble JT, Stouthamer R, Paine TD (2008) New Huanglongbing (HLB) Candidatus species, "C. Liberibacter psyllaurous", found to infect tomato and potato is vectored by the psyllid Bactericera cockerelli (Sulc). Appl Environ Microbiol 74:5862-5865

Harmon JP, Moran NA, Ives AR (2009) Species response to environmental change: impacts of food web interactions and evolution. Science 323:1347-1350

Harper AM, Miska JP, Manglitz GR, Irwin BJ, Armbrust EJ (1978) The literature of arthropods associated associated with alfalfa. III. A bibliography of Acrythosiphon pisum. Agricultural Experimental Station, University of Illinois, Urbana-Champaign, pp 1-89, Special Publication 50

Haugen DA (1990) Control procedures for Sirex noctilio in the Green Triangle: review from detection to severe outbreak (1977-87). Austral Forest 53:24-32 
Haugen DA, Underdown MG (1993) Reduced parasitism of Sirex noctilio in radiata pines inoculated with the nematode Beddingia siricidicola during 1974-89. Austral Forest 56:45-48

Henter HJ, Via S (1995) The potential for coevolution in a host-parasitoid system. I. Genetic variation within an aphid population in susceptibility to a parasitic wasp. Evolution 49:427-438

Hicke JA, Logan JA, Powell J, Ojima DS (2006) Changing temperatures influence suitability for modeled mountain pine beetle (Dendroctonus ponderosae) outbreaks in the western United States. J Geophys Res 3:G02019

Hill RE (1947) An unusual weather sequence accompanying the severe potato psyllid outbreak in 1938 in Nebraska. J Kansas Entomol Soc 20:88-92

Hoebeke ER, Haugen DA, Haack RA (2005) Sirex noctilio: discovery of a Palearctic siricid woodwasp in New York. Newsl Mich Entomol Soc 50:24-25

Hofstetter RW, Klepzig KD, Moser JC, Ayres MP (2006a) Seasonal dynamics of mites and fungi and their interactions with southern pine beetle. Environ Entomol 35:22-30

Hofstetter RW, Cronin J, Klepzig KD, Moser JC, Ayres MP (2006b) Antagonisms, mutualisms and commensalisms affect outbreak dynamics of the southern pine beetle. Oecologia 147:679-691

Hölldobler B, Wilson EO (1990) The ants. Harvard University Press, Cambridge

Hosokawa T, Kikuchi Y, Shimada M, Fukatsu T (2007) Obligate symbiont involved in pest status of host insect. Proc R Soc Lond B 274:1979-1984

Hurley BP, Slippers B, Wingfield MJ (2007) A comparison of control results for the alien invasive woodwasp, Sirex noctilio, in the southern hemisphere. Agric For Entomol 9:159-171

Hurley BP, Slippers B, Croft PK, Hatting HH, van der Linde M, Morris AR, Dyer C, Wingfield MJ (2008) Factors influencing parasitism of Sirex noctilio (Hymenoptera:Siricidae) by the nematode Deladenus siricidicola (Nematoda: Neotylenchidae) in summer rainfall areas of South Africa. Biol Control 45:450-459

IPCC WGII (2007) Working group II contribution to the intergovernmental panel on climate change, fourth assessment report. Climate change 2007: climate change impacts, adaptation and vulnerability. Summary for policy makers. www.ipcc.ch/SPM6avr07.pdf

Ito S, Yamada T (1998) Distribution and spread of mass mortality of oak trees. J Jpn Forest Soc 80:229-232, In Japanese, referenced from Kamata et al. 2002

Jacobs K, Bergdahl DR, Wingfield MJ, Halik S, Seifert KA, Bright DE, Wingfield BD (2004) Leptographium wingfieldii introduced into North America and found associated with the exotic Tomicus piniperda and native bark beetles. Mycol Res 108:411-418

Janson EM, Stireman JO III, Singer MS, Abbot P (2009) Phytophagous insect-microbe mutualisms and adaptive evolutionary diversification. Evolution 62:997-1012

Jones JA (1990) Termites, soil fertility and carbon cycling in dry tropical Africa: a hypothesis. J Trop Ecol 6:291-305 
Jonkman JCM (1978) Nest of the leaf-cutting ant, Atta wollenweideri, as accelerators of succession in pastures. Zeit Ange Ent 86:25-34

Kamata N, Esaki K, Kato K, Igeta Y, Wada K (2002) Potential impact of global warming on deciduous oak die-back caused by ambrosia fungus Raffaelea sp. carried by ambrosia beetle Platypus quercivorus (Coleoptera: Platypodidae). Bull Entomol Res 92:119-126

Keane RE, Ryan KC, Veblen T, Allen CD, Logan JA, Hawes B (2002) The cascading effects of fire exclusion in Rocky Mountain ecosystems. USDA FS General Technical Report RMRS-GTR-91. 24 $\mathrm{p}$

Kiers TE, Palmer TM, Ives AR, Bruno JF, Bronstein JL (2010) Mutualisms in a changing world: an evolutionary perspective. Ecol Lett. doi:10.1111/j.1461-0248.2010.01538.x

Kirkendall LR (1993) Ecology and evolution of biased sex ratios in bark and ambrosia beetles. In: Wrensch DL, Ebbert MA (eds) Evolution and diversity of sex ratio in insects and mites. Chapman and Hall, New York, pp 235-345

Kok LT, Norris DM, Chu HM (1970) Sterol metabolism as a basis for mutualistic symbiosis. Nature 225:661-662

Konate S, Le Roux X, Verdier B, LePage M (2003) Effect of underground fungus-growing termites on carbon dioxide emission at the point- and landscape scales in an African savanna. Funct Ecol $17: 305-314$

Kowero G, Kufukwandi F, Chipeta M (2006) Africa's capacity to manage its forests: an overview. Int For Rev 8:110-117

Kubono T, Ito S (2002) Raffaelea quercivora sp. nov. associated with mass mortality of Japanese oak, and the ambrosia beetle (Platypus quercivorus). Mycoscience 43:255-260

Kühnholn S, Borden JH, Uzonovic A (2003) Secondary ambrosia beetles in apparently healthy trees: adaptations, potential causes and suggested research. Integr Pest Manag Rev 6:209-219

Kukor JJ, Martin MM (1983) Acquisition of digestive enzymes by siricid woodwasps from their fungal symbiont. Science 220:1161-1163

Kurz WA, Dymond CC, Stinson G, Rampley GJ, Nelson ET, Carroll AL, Ebata T, Safranyik L (2008) Mountain pine beetle and forest carbon feedback to climate change. Nature 452:987-990

Leal IR, Oliveira PS (1998) Interactions between fungus-growing ants (Attini), fruits and seeds in Cerrado vegetation in Southeast Brazil. Biotropica 30:170-178

Ledig FT (1992) Human impacts on genetic diversity in forest ecosystems. Oikos 63:87-108

Lee S, Breuil C, Hamelin R, Six DL (2007) Genetic diversity and the presence of two distinct groups in Ophiostoma clavigerum associated with the mountain pine beetle, Dendroctonus ponderosae in British Columbia and the northern Rocky Mountains. Phytopathol 97:1177-1185

Lee JC, Aguayo I, Aslin R, Durham G, Hamud SH, Ragenovich BD, Witcosky JJ, Seybold SJ (2009) Co-occurrence of the invasive banded and European elm bark beetles in North America. Ann Entomol Soc Am 102:426-436 
LePage M, Abbadie L, Mariotti A (1993) Food habits of sympatric termite species (Isoptera, Macrotermitinae) as determined by stable carbon isotope analysis in a Guinnean savanna (Lamto, Cote d' Ivoire). J Trop Ecol 9:303-311

Lindenmayer DB, Noss R (2006) Salvage logging, ecosystem processes, and biodiversity conservation. Conserv Biol 20:949-958

Little AEF, Currie CR (2007) Symbiotic complexity: discovery of a fifth symbiont in the attine antmicrobe symbiosis. Biol Lett 3:501-504

Little AEF, Currie CR (2008) Black yeast symbionts compromise the efficiency of antibiotic defense in fungus-growing ants. Ecology 89:1216-1222

Logan JA, MacFarlane WW (2010) Beetle devastates Yellowstone whitebark pine forests. Action bioscience http://www.actionbioscience.org/environment/loganmacfarlane.html?print

Logan JA, Bentz BJ, Powell JA (2002) Ghost forests, global warming and the mountain pine beetle. Am Entomol 47:160-173

Logan JA, Regniere J, Powell JA (2003) Addressing impacts of global warming on forest pest dynamics. Front Ecol Environ 1:130-137

Lombardero MJ, Ayres MP, Hofstetter RW, Moser JC, Klepzig KD (2003) Strong indirect interactions of Tarsonemus mites (Acarina: Tarsonemidae) and Dendroctonus frontalis (Coleoptera: Scolytidae). Oikos 102:243-252

Lu Q, deCock C, Zhang XY, Maraite H (2008) Leptographium sinoprocerum sp. nov., and undescribed species associated with Pinus tabuliformis-Dendroctonus valens in northern China. Mycologia 100:275-290

Lu Q, deCock C, Zhang XY, Maraite H (2009a) Ophiostomatoid fungi (Ascomycota) associated with Pinus tabuliformis infested by Dendroctonus valens (Coleoptera) in northern China and an assessment of their pathogenicity on mature trees. Antonie Leeuwenhoek 96:275-293

Lu M, Zhou XD, DeBeer ZW, Wingfield MJ, Sun J-H (2009b) Ophiostomatoid fungi associated with the invasive pine-infesting bark beetle, Dendroctonus valens, in China. Fungal Divers 38:133145

Mackauer M, Campbell A (1972) The establishment of three exotic parasites (Hymenoptera: Aphidiidae) in British Columbia. J Entomol Soc BC 69:54-58

Madden JL (1988) Sirex in Australasia. In: Berryman AA (ed) Dynamics of forest insect populations patterns, causes, implications. Plenum, New York, pp 407-429

Madden JL, Coutts MP (1979) The role of fungi in the biology and ecology of woodwasps (Hymenoptera: Siricidae). In: Batra LR (ed) Insect-fungus symbiosis. Allanheld, Osmun \& Co., Montclair, pp 165-174

Margulis L, Fester R (1991) Symbiosis as a source of evolutionary innovation: speciation and morphogenesis. The MIT, Cambridge 
Massoumi-Alamouti S, Tsui CKM, Breuil C (2009) Multi-gene phylogeny of filamentous ambrosia fungi associated with ambrosia and bark beetles. Mycol Res 113:822-835

Mayhé-Nunes AJ, Jaffe K (1998) On the biogeography of Attini (Hymenoptera: Formicidae). Ecotropicos 11:45-54

Maynard Smith J, Szathmary E (1995) The major transitions in evolution. WH Freeman, New York

McCullough DG, Werner RA, Neumann D (1998) Fire and insects on northern and boreal forest ecosystems of North America. Annu Rev Entomol 43:107-122

Mikheyev AS, Mueller UG, Boomsma JJ (2007) Population genetic signatures of diffuse coevolution between leaf-cutting ants and their cultivar fungi. Mol Ecol 16:209-216

Mira A, Moran N (2002) Estimating population size and transmission bottlenecks in maternally transmitted endosymbiotic bacteria. Microb Ecol 44:137-143

Mireku E, Simpson JA (2002) Fungal and nematode threats to Australian forests and amenity trees from importation of wood and wood products. Can J Plant Pathol 24:117-124

Moir ML, Brennan KEC (2007) Using bugs (Hemiptera) as ecological and environmental indicators in forest ecosystems. In: Verne NC (ed) Forest ecology research horizons. Nova, New York, pp $203-238$

Möller AFW (1893) Die Pilzgärten einiger südamerikanischer Ameisen. Gustav Fischer Verlag, Jena, Germany

Montllor CB, Maxmen A, Purcell AH (2002) Facultative bacterial endosymbionts benefit pea aphids Acyrthosiphon pisum under heat stress. Ecological Ent 27:189-195

Morales-Ramos JA, Rojas G, Sittertz-Bhatkar H, Saldana G (2000) Symbiotic relationship between Hypothenemus hampei (Coleoptera: Scolytidae) and Fusarium solani (Moniliales: Tuberculariaceae). Ann Entomol Soc Am 93:541-547

Moran NA, Degnan PH, Santos SR, Dunbar HE, Ochman H (2005) The players in a mutualistic symbiosis: insects, bacteria, viruses and virulence genes. PNAS 102:16919-16926

Moran NA, McCutcheon JP, Nakabachi A (2008) Genomics and evolution of heritable bacterial symbionts. Annu Rev Genet 42:165-190

Morgan FD (1968) Bionomics of siricidae. Annu Rev Entomol 13:239-256

Morgan FD (1984) Psylloidea of South Australia. SAGPO, Adelaide

Mueller UG, Rehner SA, Schultz TR (1998) The evolution of agriculture in ants. Science 281:2034-2038

Mueller UG, Schultz TR, Currie CR, Adams RMM, Malloch D (2001) The origin of the attine antfungus mutualism. Quart Rev Biol 76:169-197

Neumann FG, Minko G (1981) The sirex woodwasp in Australian radiata pine plantations. Austral Forest 44:46-63 
Nielsen C, Williams DW, Hajek AE (2009) Putative source of the invasive Sirex noctilio fungal symbiont, Amylostereum areolatum, in the eastern United States and its association with native siricid woodwasps. Mycol Res 113:1242-1253

Normark BB, Jordahl BH, Farrell BD (1999) Origin of a haplodiploid beetle lineage. Proc R Soc Lond B 266:2253-2259

Norris DM (1979) The mutualistic fungi of Xyleborini beetles. In: Batra LR (ed) Insect-fungus symbiosis: nutrition, mutualism, and commensalism. Allanheld, Osmun, and Co, New Jersey, pp $53-64$

Nováková E, Hypša V, Moran N (2009) Arsenophonus, an emerging clade of intracellular symbionts with a broad host distribution. BMC Microbiol 9:143

Oh DC, Poulsen M, Currie CR, Clardy J (2009) Dentigerumycin, the bacterially produced molecular mediator of a fungus-growing ant symbiosis. Nat Chem Biol 5:391-393

Ohkuma M (2003) Termite symbiotic systems: efficient bio-recycling of lignocellulose. Appl Microbiol Biotech 61:1-9

Oliver KM, Russell JA, Moran NA, Hunter MS (2003) Facultative bacterial symbionts in aphids confer resistance to parasitic wasps. PNAS 100:1803-1807

Oliver KM, Moran NA, Hunter MS (2005) Variation in resistance to parasitism in aphids is due to symbionts not host genotype. PNAS 102:12795-12800

Oliver KM, Moran NA, Hunter M (2006) Costs and benefits of a superinfection of facultative symbionts in aphids. Proc R Soc Lond B 273(1591):1273-1280

Oliver KM, Degnan PH, Hunter MS, Moran NA (2009) Bacteriophages encode factors required for protection in a symbiotic mutualism. Science 325:992-994

Oliver KM, Degnan PH, Burke GR, Moran NA (2010) Facultative symbionts of aphids and the horizontal transfer of ecologically important traits. Annu Rev Entomol 55:247-266

Paine TD, Millar JG (2002) Insect pests of eucalyptus in California: implications of managing invasive species. Bull Entomol Res 92:147-151

Paine TD, Dahlsten DL, Millar JG, Hoddle MS, Hanks LM (2000) UC scientists apply IPM techniques to new eucalyptus pests. Calif Agric 54:8-13

Parmesan C, Yohe G (2003) A globally coherent fingerprint of climate change impacts across natural systems. Nature 421:37-42

Paulin-Mahady AE, Harrington TC, McNew D (2002) Phylogenetic and taxonomic evaluation of Chalara, Chalaropsis, and Thielaviopsis anamorphs associated with Ceratocystis. Mycologia 94:62-72

Perkins TE, Matlack GR (2002) Human-generated pattern in commercial forests of southern Mississippi and consequences for spread of pests and pathogens. For Ecol Manag 157:143-154 
Perotti MA, Allen JM, Reed DL, Braig HR (2007) Host-symbiont interactions of the primary endosymbiont of human head and body lice. J Fed Amer Soc Exp Biol 21:1058-1066

Pinto-Tomás AA, Anderson MA, Suen G, Stevenson DM, Chu FST, Wallace Cleland W, Weimer PJ, Currie CR (2009) Symbiotic nitrogen fixation in the fungus gardens of leaf-cutter ants. Science 326:1120-1123

Poulsen M, Cafaro MJ, Boomsma JJ, Currie CR (2005) Specificity of the mutualistic association between actinomycete bacteria and two sympatric species of Acromyrmex Leaf-cutting ants. Mol Ecol 14:3597-3604

Poulsen M, Fernández-Marin H, Currie CR, Boomsma JJ (2009) Ephemeral windows of opportunity maintain horizontal transmission of fungal symbionts in leaf-cutting ants. Evolution 63:2235-2247

Poulsen M, Cafaro MJ, Erhardt D, Gerardo NM, Little A, Tebbets B, Klein B, Currie CR (2010) Variation in Pseudonocardia antibiotic defense helps govern parasite-induced morbidity in Acromyrmex leaf-cutting ants. Environ Microbiol Rep 2:534-540

Pringle RM, Doak DF, Brody AK, Jocque R, Palmer TM (2010) Spatial Pattern enhances ecosystem functioning in an African savanna. Plos Biology 8

Raffa KF, Aukema BH, Bentz BJ, Carroll AL, Hicke JA, Turner MG, Romme WH (2008) Crossscale drivers of natural disturbance prone to anthropogenic amplification: the dynamics of bark beetle eruptions. Bioscience 58:501-517

Régneirè J, Bentz BJ (2007) Modeling cold tolerance in the mountain pine beetle, Dendroctonus ponderosae. J Insect Physiol 53:559-572

Reynolds HT, Currie CR (2004) Pathogenicity of Escovopsis weberi: the parasite of the attine antmicrobe symbiosis directly consumes the ant-cultivated fungus. Mycologia 96:955-959

Rice AV, Thormann MN, Langor DW (2008) Mountain pine beetle-associated blue-stain fungi are differentially adapted to boreal temperatures. For Path 38:113-123

Rouland-Lefevre C, Mora P (2002) Control of Ancistrotermes guineensis Silvestri (Termitidae: Macrotermitinae), a pest of sugarcane in Chad. Int J Pest Manag 48:81-86

Roux J, Kamgan NG, Ott E, Six DL (2010) First report of Xylosandrus crassiasculus and its ambrosia symbiont in South Africa. S Afr J Bot (In Prep)

Russell JA, Moran NA (2006) Costs and benefits of symbiont infection in aphids: variation among symbionts and across temperatures. Proc R Soc B 273(1586):603-610

Sandström JA, Russell J, White JP, Moran NA (2001) Independent origins and horizontal transfer of bacterial symbionts of aphids. Mol Ecol 10:217-228

Saunders DA, Hobbs RJ, Margules CR (1991) Biological consequences of ecosystem fragmentation: a review. Conserv Biol 5:18-32

Scarborough CL, Ferrari J, Godfray HJJ (2005) Aphid protected from pathogen by endosymbiont. Science 310:1781 
Schowalter TD, Zhang Y (2005) Canopy arthropod assemblages in four overstory and three understory plant species in a mixed-conifer old-growth forest in California. For Sci 51:233-242

Schultz TR, Brady S (2008) Major evolutionary transitions in ant agriculture. PNAS 105:54355440

Schuurman G (2005) Decomposition rates and termite assemblage composition in semiarid Africa. Ecology 86:1236-1249

Shigenobu S, Watanabe H, Hattori M, Sakaki Y, Ishikawa H (2000) Genome sequence of the endocellular bacterial symbiont of aphids Buchnera sp. APS. Nature 407:81-86

Sileshi GW, Nyeko P, Nkunika POY, Sekematte BM, Akinnifesi FK, Ajayi OC (2009) Integrating ethno-ecological and scientific knowledge of termites for sustainable termite management and human welfare in Africa. Ecology and Society 14: 48. [online] URL: http://www.ecologyandsociety.org/vol14/iss1/art48/

Six DL (2003) Bark beetle-fungus symbioses. In: Bourtzis K, Miller TA (eds) Insect symbiosis. CRC, New York, pp 97-114

Six DL (2009) Climate change and mutualism. Nat Rev Microbiol 7:686

Six DL, Bentz BJ (2007) Temperature determines the relative abundance of symbionts in a multipartite bark beetle-fungus symbiosis. Microb Ecol 54:112-118

Six DL, Klepzig KD (2004) Dendroctonus bark beetles as model systems for the study of symbiosis. Symbiosis 37:207-232

Six DL, Paine TD (1998) Effects ofmycangial fungi and host tree species on progeny survival and emergence of Dendroctonus ponderosae (Coleoptera: Scolytidae). Environ Entomol 27:1393-1401

Six DL, Wingfield MJ (2011) The role of phytopathogenicity in bark beetle-fungus symbioses: a challenge to the classic paradigm. Annu Rev Entomol 56:255-272

Six DL, Stone WD, de Beer ZW, Woolfolk SW (2009) Ambrosiella beaveri, sp. nov., associated with an exotic ambrosia beetle, Xylosandrus mutilatus, in Mississippii, USA. Antonie Leeuwenhoek 96:17-29

Slippers B, Wingfield BD, Coutinho TA, Wingfield MJ (2002) DNA sequence and RFLP data reflect geographical spread and relationships of Amylostereum areolatum and its insect vectors. Mol Ecol 11:1845-1854

Slippers B, Coutinho TA, Wingfield BD, Wingfield MJ (2003) The genus Amylostereum and its association with woodwasps: a contemporary review. S Afr J Sci 99:70-74

Spradbery JP, Kirk AA (1978) Aspects of the ecology of siricid woodwasps (Hymenoptera: Siricidae) in Europe, North Africa and Turkey with special reference to the biological control of Sirex noctilio F. in Australia. Bull Entomol Res 68:341-359

Stone WE, Wolfe ML (1996) Response of understory vegetation to variable tree mortality following mountain pine beetle epidemic in lodgepole pine stands in northern Utah. Vegetatio 122:1-12 
Stone WD, Nebeker TE, Gerard PD (2007) Host plants of Xylosandrus mutilatus in Mississippi. Fla Entomol 90:191-195

Subandiyah S, Nikoh N, Tsuyumu S, Somowiyarjo S, Fukatsu T (2000) Complex endosymbiotic microbiota of the citrus psyllid Diaphorina citri (Homoptera: Psylloidea). Zool Sci 17:983-989

Taerum SJ, Cafaro MJ, Little AEF, Schultz TR, Currie CR (2007) Low host-pathogen specificity in the leaf-cutting ant-microbe symbiosis. Proc R Soc Lond B 274:1971-1978

Talbot PHB (1977) The Sirex-Amylostereum-Pinus association. Annu Rev Phytopathol 15:41-54

Taylor SW, Carroll AL (2004) Disturbance, forest age, and mountain pine beetle dynamics in British Columbia: a historical perspective. Proceedings mountain pine beetle symposium: challenges and solutions. October 30-31. Kelowna, British Columbia, Canada. Pacific Forestry Centre Information Report BC-X-399. P. 41-51

Thomas CD, Franco A, Hill JK (2006) Range retractions and extinctions in the face of climate warming. TREE 21:415-416

Trowbridge RE, Dittmar K, Whiting MF (2006) Identification and phylogenetic analysis of Arsenophonus- and Photorhabdus-type bacteria from adult Hippoboscidae and Streblidae (Hippoboscoidea). J Invert Pathol 91:64-68

Tsuchida T, Koga R, Fukatsu T (2004) Host plant specialization governed by facultative symbiont. Science 303:1989

Turner JS (2001) On the mound of Macrotermes michaelseni as an organ of respiratory gas exchange. Physiol Biochem Zool 74:798-822

USDA (1994) Importation of logs, lumber, and other unmanufactured wood articles, environmental impact statement. USDA, Animal and Plant Inspection Service, Hyattsville, 48

Vasconcelos HL, Araújo BB, Mayhe-Nunes AJ (2008) Patterns of diversity and abundance of fungus-growing ants (Formicidae: Attini) in areas of the Brazilian Cerrado. Rev Bras Zoologia $25: 445-450$

von Ihering H (1898) Die Anlagen neue Colonien und Pilzgärten bei Atta sexdens. Zool Anz 21:238-245

Vorburger C, Gehrer L, Rodriguez P (2010) A strain of the bacterial symbiont Regiella insecticola protects aphids against parasitoids. Biol Lett 6:109-111

Wade TG, Ritters KH, Wickham JD, Jones KB (2003) Distribution and causes of global forest fragmentation. Conserv Ecol 7:7

Weber NA (1966) Fungus-growing ants. Science 153:587-604

Weber NA (1972) Gardening ants: the attines. Mem Amer Phil Soc 92:1-142

White TCR (1971) Lerp insects (Homoptera: Psyllidae) on red gum (E. camaldulensis) in South Australia. S Aust Nat 46:20-23 
Williamson M (1996) Biological invasions. Chapman and Hall, London

Wingfield MJ, Slippers B, Wingfield BD (2010) Novel associations between pathogens, insects and tree species threaten world forests. N Z J For Sci 40(suppl):S95-S103

Wirth R, Herz H, Ryel RJ, Beyschlag W, Hölldobler B (2003) Herbivory of leaf-cutting ants. A case study on Atta colombica in the tropical rain forest of Panama, Ecological studies. Springer, Berlin, $p$ xvi, 230

Wood SL (1982) The bark and ambrosia beetles of North and Central America (Coleoptera: Scolytidae), a taxonomic monograph. Great Basin Nat Mem 6:1-1359

Wood TG (1996) The agricultural importance of termites in the tropics. Agric Zool Rev 7:117-155

Wood T, Sands W (1978) The role of termites in ecosystems. In: Brian M (ed) Production ecology of ants and termites. Cambridge University Press, Cambridge, pp 245-292

Wood TG, Johnson RA, Ohiagu CE (1980) Termite damage and crop loss studies in Nigeria - a review of termite (Isoptera) damage to maize and estimation of damage loss in yield and termite (Microtermes) abundance at Mokuna. Intl J Pest Mgmt 26:241-253

Wylie FR, Peters BC (1993) Insect pests of eucalypt plantations in Australia. 1. Queensland. Austral For 56:358-362

Yan ZL, Owen D, Zhang ZN (2005) The red turpentine beetle, Dendroctonus valens LeConte (Scolytidae): An exotic invasive pest in China. Biodivers Conserv 14:1735-1760

Yukawa J (1984) An outbreak of Crypticerya jacobsoni (Green) (Homoptera: Margarodidae) on Rakata Besar of the Krakatau Islands in Indonesia. Appl Entomol Zool 19:179-180 